\title{
ГИДРОГЕОХИМИЯ ВЕНДА СИБИРСКОЙ ПЛАТФОРМЫ
}

\author{
Новиков Д. А., Черных А. В., Константинова Л. Н., Дульцев Ф. Ф., Юрчик И. И.
}

\begin{abstract}
Аннотация
Вендские отложения Сибирской платформы представлены четырьмя региональными горизонтами (снизу-вверх): непским, вилючанским, тирским и даниловским. Величина общей минерализации рассолов непского и вилючанского горизонта варьирует в интервале от 170,3 до 470,1 г/дм3, в вышезалегающих тирском и даниловском горизонтах - от 84,6 до 583,1 г/дм3. Выявлены рассолы $\mathrm{Cl} \mathrm{Na}, \mathrm{Cl} \mathrm{Na-Ca,} \mathrm{Cl} \mathrm{Ca-Na,} \mathrm{Cl} \mathrm{Ca} \mathrm{и} \mathrm{Cl} \mathrm{Ca-Mg} \mathrm{типов.} \mathrm{Преобладают} \mathrm{кислые} \mathrm{и} \mathrm{слабокислые} \mathrm{рассолы}$ $(\mathrm{pH}=3,0-5,5)$ с вариацией значений $\mathrm{pH}$ от 3,0 до 7,0. Значения окислительно-восстановительного потенциала Еh изменяется от резко восстановительных -440 мВ до окислительных +130 мВ, при средних значениях -176 мВ.
\end{abstract}

Площадная региональная гидрогеохимическая зональность контролируется местоположением внешних, развитых по периферии Сибирской платформы, где протекали процессы инфильтрации метеорных вод, и внутренних областей питания.

Во внешних областях питания развиты разновозрастные инфильтрогенные рассолы (группа I), преимущественно хлоридного натриевого состава. Они характеризуются величиной общей минерализации до 280 г/дм3, повышенным $\mathrm{rNa} / \mathrm{rCl}$ (до 1,55), Cl/Br (до 2512) и Сa/Cl (в среднем $0,3)$ отношениями. Средние величины интегрированного показателя метаморфизации рассолов $\mathrm{S}$ (по С.Л. Шварцеву) составляют от 50 до 200.

С внутриплатформенными зонами (областями) питания связано несколько фаз гравитационного опускания в вендские горизонты рассолов периодов существования на платформе кембрийских солеродных бассейнов, которые претерпели метаморфизм в процессе фильтрации по зонам трещиноватости и разломов. Внедрение траппов в конце перми - начале триаса и сопровождающая его гидротермальная деятельность за счет нагрева интрузиями вмещающих кембрийские доломитовые горизонты вод до температур 800-1000 оС привели при взаимодействии этих вод с карбонатными породами, эвапоритами, в частности с хлоридными солями к формированию сверхкрепких и предельно насыщенных рассолов. Эти сверхкрепкие и предельно насыщенные рассолы также подвергались гравитационному опусканию в вендские резервуары. Поступление в вендские резервуары метаморфизованных крепких и сверхкрепких рассолов явилось основной причиной инверсионной вертикальной гидрогеохимической зональности в подсолевой гидрогеологической формации.

Процессы метаморфизма рассолов и изменение температурного режима недр при внедрении интрузий траппов и их последующем остывании привело в процессах взаимодействия «рассолы породы» к значительному изменению вмещающих горных пород, засолонению коллекторов, росту общей минерализации рассолов и катагенетическим изменениям их состава. Наиболее близкие к состоянию предельного насыщения к галиту рассолы установлены в зонах наибольшего засолонения коллекторов, а также вблизи разломов или границ интрузивных тел. Во время предвилючанского, преднепского, предтирского и предданиловского перерывов в осадконакоплении в вендские отложения проникали инфильтрогенные воды. В геохимическом плане седиментогенно-инфильтрогенно-метаморфические крепкие рассолы (группа II) имеют преимущественно хлоридный кальциевый и кальциево-магниевый состав с величиной общей минерализации, превышающей 350 г/дм3. Для них характерны низкие значения $\mathrm{rNa} / \mathrm{rCl}$ (в среднем 0,3), Cl/Br (до 100), повышенные значения $\mathrm{Ca} / \mathrm{Cl}$ (в среднем 0,4) коэффициентов. Значения показателя S составляют более 250. 


\section{Ключевые слова:}

Гидрогеохимия, сверхкрепкие рассолы, кембрий, венд, степень метаморфизации, генетический тип, трапповый магматизм, Сибирская платформа 


\title{
ГИДРОГЕОХИМИЯ ВЕНДА СИБИРСКОЙ ПЛАТФОРМЫ
}

\author{
() 2021 г. Д.А. Новиков ${ }^{1,2 *}$, А.В. Черных ${ }^{1}$, Л.Н. Константинова ${ }^{1}$, Ф.Ф. Дульцев ${ }^{1}$,
}

И.И. Юрчик ${ }^{1}$

\author{
${ }^{1}$ Институт нефтегазовой геологии и геофизики им. А.А. Трофимука СО РАН \\ Россия, 630090 Новосибирск, проспект Академика Коптюга, 3 \\ ${ }^{2}$ Новосибирский национальный исследовательский государственный университет \\ Россия, 630090 Новосибирск, ул. Пирогова, 1 \\ *E-mail: NovikovDA@ipgg.sbras.ru \\ Поступила в редакцию 00.00.2019
}

Вендские отложения Сибирской платформы представлены четырьмя региональными горизонтами (снизу-вверх): непским, вилючанским, тирским и даниловским. Величина общей минерализации рассолов непского и вилючанского горизонта варьирует в интервале от 170,3 до 470,1 г/дм³ в вышезалегающих тирском и даниловском горизонтах - от 84,6 до 583,1 г/дм³. Выявлены рассолы $\mathrm{Cl} \mathrm{Na}, \mathrm{Cl} \mathrm{Na-Ca,} \mathrm{Cl} \mathrm{Ca-Na,} \mathrm{Cl} \mathrm{Ca} \mathrm{и} \mathrm{Cl} \mathrm{Ca-Mg} \mathrm{типов.} \mathrm{Преобладают} \mathrm{кислые} \mathrm{и} \mathrm{слабокислые} \mathrm{рассолы} \mathrm{(pH} \mathrm{=}$ 3,0 - 5,5) с вариацией значений $\mathrm{pH}$ от 3,0 до 7,0. Значения окислительно-восстановительного потенциала Еh изменяется от резко восстановительных -440 мВ до окислительных +130 мВ, при средних значениях $-176 \mathrm{MB}$.

Площадная региональная гидрогеохимическая зональность контролируется местоположением внешних, развитых по периферии Сибирской платформы, где протекали процессы инфильтрации метеорных вод, и внутренних областей питания.

Во внешних областях питания развиты разновозрастные инфильтрогенные рассолы (группа I), преимущественно хлоридного натриевого состава. Они характеризуются величиной общей минерализации до 280 г/дм³ отношениями. Средние величины интегрированного показателя метаморфизации рассолов $\mathrm{S}$ (по С.Л. Шварцеву) составляют от 50 до 200.

С внутриплатформенными зонами (областями) питания связано несколько фаз гравитационного опускания в вендские горизонты рассолов периодов существования на платформе кембрийских солеродных бассейнов, которые претерпели метаморфизм в процессе фильтрации по зонам трещиноватости и разломов. Внедрение траппов в конце перми - начале триаса и сопровождающая его гидротермальная деятельность за счет нагрева интрузиями вмещающих кембрийские доломитовые горизонты вод до температур 800-1000 ${ }^{\circ} \mathrm{C}$ привели при взаимодействии этих вод с карбонатными породами, эвапоритами, в частности с хлоридными солями к формированию сверхкрепких и предельно насыщенных рассолов. Эти сверхкрепкие и предельно насыщенные рассолы также подвергались гравитационному опусканию в вендские резервуары. Поступление в вендские резервуары метаморфизованных крепких и сверхкрепких рассолов явилось основной причиной инверсионной вертикальной гидрогеохимической зональности в подсолевой гидрогеологической формации.

Процессы метаморфизма рассолов и изменение температурного режима недр при внедрении интрузий траппов и их последующем остывании привело в процессах взаимодействия «рассолы породы» к значительному изменению вмещающих горных пород, засолонению коллекторов, росту общей минерализации рассолов и катагенетическим изменениям их состава. Наиболее близкие к состоянию предельного насыщения к галиту рассолы установлены в зонах наибольшего засолонения коллекторов, а также вблизи разломов или границ интрузивных тел. Во время предвилючанского, преднепского, предтирского и предданиловского перерывов в осадконакоплении в вендские отложения проникали инфильтрогенные воды. В геохимическом плане седиментогенно-инфильтрогенно-метаморфические крепкие рассолы (группа II) имеют преимущественно хлоридный кальциевый и кальциево-магниевый состав с величиной общей минерализации, превышающей 350 г/дм ${ }^{3}$. Для них характерны низкие значения $\mathrm{rNa} / \mathrm{rCl}$ (в среднем 0,3), $\mathrm{Cl} / \mathrm{Br}$ (до 100), повышенные значения $\mathrm{Ca} / \mathrm{Cl}$ (в среднем 0,4) коэффициентов. Значения показателя S составляют более 250.

Гидрогеохимия, сверхкрепкие рассолы, кембрий, венд, степень метаморфизации, генетический тип, трапповый магматизм, Сибирская платформа.

\section{ВВЕДЕНИЕ}


Сверхкрепкие хлоридные кальциевые рассолы распространены не только на Сибирской платформе. Они вскрыты бурением и горными выработками при поисковоразведочном бурении в глубоких горизонтах в Долине смерти (Калифорния) [Lowenstein, Risacher, 2009], солянокупольном бассейне Миссисипи [Kharaka et al., 1987; Kharaka, Hanor, 2003], Канадском щите [Frape, Fritz, 1987; Bottomley et al., 1999; Stotler et al., 2009], Богемском массиве [Paces, 1987; Möller et al., 1997; Möller et al., 2005; Stober, Bucher, 2005], Северо-Германском бассейне [Möller et al., 2017] и других.

Среди более чем 30 верхнепротерозойских нефтегазоносных бассейнов мира [Конторович и др., 1996а] с доказанной промышленной нефтегазоносностью, с нефте- и газопроявлениями, а также с вероятной нефтегазоносностью рассолы вендских отложений в наибольшей мере изучены в Лено-Тунгусском бассейне [Валяшко, 1962, Пиннекер, 1966, Анциферов, 1971, Конторович, Сурков, Трофимук, 1981, Вожов, 2006; Novikov et al., 2018].

Исследование особенностей гидрогеология, геотермических и гидродинамических условий, гидрогеохимии Сибирской платформы было начато еще в 60-х годах прошлого столетия и связано с именами М.Г. Валяшко, Е.В. Ильиной, В.Г. Ткачук и Е.В. Пиннекера [Валяшко, 1962; Ильина и др., 1962; Валяшко и др., 1965; Пиннекер, 1966]. Позднее гидрогеологические аспекты рассматривали А.С. Анциферов, А.Э. Конторович, В.И. Вожов, С.Л. Шварцев, М.Б. Букаты, С.В. Алексеев и многие другие [Афанасьев и др., 1968; Анциферов и др., 1971; Афанасьев и др., 1972; Басков, 1976; Вожов, 1977; Павленко и др., 1978; Анциферов и др., 1981; Вожов, 1987; Анциферов, 1989; Шварцев, Букаты, 1995; Шварцев 2000; Вожов, 2006; Алексеев и др., 2007; Сидкина, Новиков, Шварцев, 2012; Novikov, Trifonov, 2016; Novikov, 2017; Алексеева, Алексеев, 2019; Каширцев и др., 2019]. Одной из характерных черт рассолов Сибирской платформы являются высокая степень минерализации до 650 г/дм², а также уникальные концентрации микрокомпонентов ( $\mathrm{Li}, \mathrm{Rb}, \mathrm{Sr}, \mathrm{Br}, \mathrm{B}$, I и других). Вендские 
комплексы являются наиболее изученными с гидрогеологической точки зрения. К ним приурочены более 50\% начальных суммарных ресурсов газа и около 18\% суммарных геологических ресурсов нефти [Конторович и др., 1975; Конторович и др., 1976; Конторович и др., 1978; Конторович и др., 1981; Бурштейн и др., 2020]. Обобщения имеющихся фактических материалов не проводилось длительное время.

\section{ОБЪЕКТ, МАТЕРИАЛЫ И МЕТОДЫ ИССЛЕДОВАНИЙ}

Вендские отложения подразделяются на две крупных толщи: нижнюю, преимущественно терригенную, которая распространена на большей части территории Сибирской платформы, и верхнюю - преимущественно карбонатную, распространенную повсеместно [Конторович и др. 1981; Решения..., 1989; Мельников и др., 2005; Мельников, 2018; Мельников, 2020]. В соответствии со стратиграфической схемой 1989 г. к региональным подразделениям отнесены горизонты и подгоризонты комплексного обоснования. Они выделены по следующим седиментационным признакам - выдержанности литологического состава, подтверждаемая прослеживанием реперов, слоев, пачек, а также стратиграфическим несогласиям и перерывам регионального значения. Количество и возрастной диапазон стратиграфических несогласий и перерывов в осадконакоплении до настоящего времени является предметом широкой дискуссии. По этим признакам разрезы венда разделены в схеме 1989 г. на три региональных стратиграфических горизонта (РСГ) непский, тирский и даниловский (рис. 1). Впоследствии в составе венда выделен вилючанский горизонт, более древний, чем непский. В последних крупных обобщениях [Мельников и др., 2005; Шемин, 2007; Мельников, 2009] дано обоснование региональных стратиграфических перерывов, проведена корреляции разрезов венда по пачкам, уточнена стратиграфическая схема венда. Длительность преднепского перерыва оценена в 15 млн лет (600-585 млн лет), а предтирского в 10 млн лет (555-545 млн лет) [Мельников, 2009]. Возраст вилючанского и непского горизонтов - 565-585 млн лет, 
тирского - 555-565 млн лет и даниловского - 535-565 млн лет [Хоментовский, Федоров, Карлова, 1998].

Вилючанский РСГ распространен на юго-западной и юго-восточной окраинах Сибирской платформы. Залежи газа выявлены на северо-востоке Непско-Ботуобинской нефтегазоносной области (НГО) на Верхневилючанском и Вилюйско-Джербинском месторождениях в песчаниках бетинчинской и хоронохской свит. В горизонт включены тыптинская и тулунская свиты Ангаро-Ленского района, хоронохская и бетинчинская свиты Предпатомско-Вилюйского района (рис. 2). В его основании фиксируется перерыв и стратиграфическое несогласие.

Непский горизонт с перерывом залегает на вилючанском, а в районах его отсутствия - с несогласием на образованиях рифея или на породах фундамента. Непский горизонт разделен на два подгоризонта, которые в основаниях как правило сложены песчаниками, а в верхних частях глинистыми породами. Непский РСГ широко распространен на юге Сибирской платформы. Толщина отложений увеличивается от центральных районов к окраинам региона от 0 до 700 м. В нижненепском подгоризонте выделены продуктивные горизонты: боханский в подошве чорской свиты на АнгароЛенской ступени, алешинский в одноименной свите тасеевской серии на Байкитской антеклизе, талахский (талахская свита) и пласт чонский II (базальный пласт непской свиты) на Непско-Ботуобинской антеклизе, пласты Вн-V, Bн-VI в ванаварской свите Катангской седловины (см. рис. 1). В верхненепском подгоризонте выделены шамановский пласт в чорской свите на Ангаро-Ленской ступени, хамакинский в паршинской свите, харыстанский ПГ в одноименной свите, марковский, ярактинский, чонский I пласты в подошве верхненепской подсвиты Непско-Ботуобинской антеклизы, пласты Вн-1-IV в ванаварской свите Катангской седловины. Все перечисленные горизонты и пласты содержат залежи углеводородов. Внутри непского регионального горизонта выделены разноранговые перерывы в осадконакоплении [Мельников, 2009]. 
Тирский горизонт соответствует тирской свите и ее возрастным аналогам (бюкская, оскобинская и др.) (см. рис. 1). В некоторых районах в основании тирского горизонта фиксируется перерыв. Тирский РСГ на Сибирской платформе развит почти повсеместно и представлен на большей части изучаемой территории терригенносульфатно-карбонатными породами. Базальные песчаники выявлены только в верхнечорской подсвите на юге Лено-Тунгусской НГП [Мельников и др., 2005]. Горизонт включает тирскую, оскобинскую, чистяковскую, космическую, бюкскую свиты и верхнюю подсвиту чорской свиты. Базальные песчаники тирского РСГ названы парфеновским ПГ в Ангаро-Ленской и на юге Непско-Ботуобинской НГО, а на севере они выделены в ботуобинский и улаханский ПГ (ботуобинская подсвита бюкской свиты). В Предпатомском фациальном районе ботуобинская подсвита составлена глинистыми породами, а верхнебюкская подсвита разделена на именные пачки нижняя телгеспитская пачка сложена доломитами, вышележащая торсальская пачка представлена каменной солью с прослоями доломитов, верхняя пачка (аянская) представлена доломито-ангидритами [Мельников, 2009]. Торсальская пачка солей вскрыта скважинами на северном замыкании Предпатомского регионального прогиба в Березовской и Нюйско-Джербинской впадинах. В Вилючанской зоне получены промышленные притоки газа из доломитов низов бюкской свиты (телгеспитская пачка). Этот продуктивный горизонт перспективен и в Ботуобинской зоне. Песчаники в средней части тирского горизонта распространены локально на севере Ангаро-Ленской ступени (братский ПГ), юге Непско-Ботуобинской антеклизы (верхнетирский ПГ в тирской свите) и на Байкитской антеклизе (пласты ЧС-I-III в чистяковской свите и пласты Б-VIII и Б-VIII-I в оморинской свите).

Даниловский горизонт верхнего венда распространен повсеместно на территории юга Лено-Тунгусской провинции (см. рис. 1). Даниловский горизонт соотносится с немакит-далдынским ярусом верхнего венда. В основании горизонта 
обосновано наличие перерыва и стратиграфического несогласия. Даниловский горизонт разделен на три четко прослеживаемых литологически выдержанных подгоризонта. Нижний соответствует объему катангской - успунской свит, средний - собинской кудулахской свит и верхний (юряхский) - тэтэрской - юряхской свит. Нижнеданиловский подгоризонт представлен в Предъенисейском фациальном районе терригенной тохомской свитой, на большей части Сибирской платформы карбонатноглинистой катангской и успунской свитами. В Туруханской фациальной зоне к нижнеданиловскому подгоризонту отнесена нижнеплатоновская подсвита. В нижней части катангской свиты выделяется преображенский продуктивный горизонт, сложенный микрофитолитовыми доломитами. Среднеданиловский региональный подгоризонт выполнен карбонатной (на юго- западе соленосно-карбонатной) собинской и карбонатной кудулахской свитами, в Туруханской зоне к среднеданиловскому подгоризонту отнесена нижняя часть среднеплатоновской подсвиты. На Байкитской антеклизе газоносны пласты карбонатов собинской свиты: Сб-I, Сб-II, Сб-III. Верхнеданиловский подгоризонт выполнен карбонатными тэтэрской, юряхской свитами и верхней частью среднеплатоновской подсвиты. Пласты карбонатов нефтегазоносны в Предпатомском районе (Юряхский продуктивный горизонт, пласты Ю-I, Ю-ІІ, Ю-ІІІ) и в Приленско-Непской зоне Непско-Ботуобинского района (Усть-Кутский продуктивный горизонт, пласты УК-I, УК-I I).

Гидрогеохимические материалы, послужившие основой для настоящей работы, были получены за длительный период времени. Электронная база данных включает результаты испытания более 823 объектов на 129 поисковых площадях и полного химического анализа (включая микрокомпоненты) 1024 проб рассолов. Выделение химических типов рассолов было проведено по классификации С.А. Щукарева, предложенной в 1934 году и основанной на формуле М.Г. Курлова. Из шести главных ионов, группируя их по два, три, четыре, пять и шесть, С.А. Щукарев получил 49 
возможных классов природных вод [Самарина, 1977]. Расчет отношений rNa/rCl, Cl/Br, $\mathrm{Ca} / \mathrm{Cl}, \mathrm{r}\left(\mathrm{HCO}_{3}+\mathrm{CO}_{3}\right) / \mathrm{r}(\mathrm{Ca}+\mathrm{Mg}), \mathrm{B} / \mathrm{Br}, \mathrm{Br} / \mathrm{Cl} \cdot 10^{-3}, \mathrm{Sr} / \mathrm{Cl} \cdot 10^{-3}$ и других позволил выявить особенности генезиса подземных рассолов. Для сравнения уровня метаморфизации нами был применен интегрированный показатель метаморфизации рассолов (S) по С.Л. Шварцеву [Шварцев, 2000], который рассчитывается по формуле:

$$
S=\frac{\frac{C a}{C l}(\text { пробы })}{\frac{C a}{C l}(\text { морской рапы })}+\frac{\frac{S r}{C l}(\text { пробы })}{\frac{S r}{C l}(\text { морской рапы })}+\frac{\frac{B r}{C l}(\text { пробы })}{\frac{B r}{C l}(\text { морской рапы })}
$$

Степень метаморфизации (катагенетических изменений) рассолов определяется по отношениям $\mathrm{Ca} / \mathrm{Cl}, \mathrm{Br} / \mathrm{Cl} \cdot 10^{-3}, \mathrm{Sr} / \mathrm{Cl} \cdot 10^{-3}$, поскольку эти процессы наиболее ярко проявляются в увеличении содержаний $\mathrm{Ca}, \mathrm{Sr}$ и $\mathrm{Br}$ за счет взаимодействия с вмещающими горными породами после их захоронения. При описании геохимических особенностей рассолов были также использованы коэффициенты $\mathrm{rNa} / \mathrm{rCl}$ и $\mathrm{Cl} / \mathrm{Br}$. (табл. 1).

\section{РЕЗУЛЬТАТЫ И ИХ ОБСУЖДЕНИЕ}

\section{Геохимия рассолов}

Хлоридные рассолы изучаемых горизонтов различаются по катионному составу от натриевых до магниевых (рис. 3). Причем, рассолы с повышенной долей магния в составе являются самыми редкими, и природа их появления требует дополнительных исследований. Они выявлены в непском, тирском и среднеданиловском горизонтах на Ванаварской, Собинской, Ковыктинской, Грузновской, Шамановской и ряде других площадей. Преобладают кислые и слабокислые рассолы (рН $=3,0-5,5)$ с вариацией значений $\mathrm{pH}$ от 3,0 до 7,0. Значения окислительно-восстановительного потенциала Еh варьируют от резко восстановительных -440 мВ до окислительных +130 мВ геохимических обстановок, при доминировании восстановительных с Eh = -176 мB. Величина общей минерализации подземных вод вендских отложений варьирует в широком интервале от 84 до 150 г/дм³ по периферии осадочного бассейна, достигая 
583,1 г/дм³ во внутренних районах Сибирской платформы. В наибольшей степени распространены рассолы с минерализацией от 280 до 400 г/дм³ [Анциферов, 1989; Вожов, 2006; Новиков и др., 2018; Novikov et al., 2018].

В непском и вилючанском региональных горизонтах развиты подземные воды с величиной общей минерализации от 170,3 г/дм³ до 470,1 г/дм³. Наибольшие значения (430-470,1 г/дм³ ${ }^{3}$ характеризуют рассолы Балаганкинской, Верхнечонской, Дулисьминской, Озерной и Преображенской площадей. Рассолы с минерализацией до 200 г/дм³ выявлены на Оморинской и Южно-Солнечной площадях (табл. 2, рис. 4).

В тирском и даниловском региональных горизонтах распространены подземные воды с минерализацией от 84,6 до 583,1 г/дм³. Рассолы с величиной общей минерализации более 500 г/дм³ выявлены на Аянской, Братской, Верхнечонской, Нижнеудинской, Огневской, Озерной, Преображенской, Собинской, Талаканской и Шамановской площадях. Слабые рассолы (менее 100 г/дм³) приурочены к Голоярской, Кийской, Мундуйской, Усть-Илимской, Чангильской, Куюмбинской и Оморинской площадям (табл. 2, рис. 5).

Особенности поведения основных катионов можно видеть на рисунке 6. Отмечается закономерная смена химических типов рассолов по мере роста общей минерализации. Среди катионов и анионов преобладают $\mathrm{Na}^{+}, \mathrm{Ca}^{2+}$ и $\mathrm{Cl}^{-}$, достигая 146,4, 192,6 и 410,6 г/дм³ соответственно. Остальные макрокомпоненты не превышают: $\mathrm{Mg}^{2+}$ 66,$2 ; \mathrm{SO}_{4}{ }^{2-}-16,0$ и $\mathrm{HCO}_{3}{ }^{-}-5,0$ г/дм ${ }^{3}$. Содержания микрокомпонентов и соединений варьируют в широких пределах и достигают: $\mathrm{Br}-11,13$ г/дм ${ }^{3}, \mathrm{NH}_{4}{ }^{+}-1,18$ г/дм ${ }^{3}$ В - 583 мг/дм³, $\mathrm{I}-924$ мг/дм ${ }^{3}, \mathrm{SiO}_{2}-102$ мг/дм³ и $\mathrm{F}-50$ мг/дм³.

Состав вендских рассолов Лено-Тунгусского бассейна [Пиннекер, 1966; Анциферов и др., 1971; Вожов, 1977; Павленко и др., 1978; Вожов, 1987; Анциферов, 1989; Шварцев, 2000] значительно отличается от таковых в Предъенисейском [Новиков, Шварцев, 2009], Волго-Уральском [Яковлев, Башкова, 2018] и Мезенском [Malov, 2001] 
бассейнах. Это выражается большей степенью их минерализации и различиями в величинах основных генетических коэффициентов. Так, значения $\mathrm{rNa} / \mathrm{rCl}$ отношения для рассолов Лено-Тунгусского бассейна варьируют в интервале от 0,22 до 1,55, составляя в среднем 0,32 - 0,63. В Предъенисейской зоне его величины составляют от 0,81 до 0,96, при среднем значении 0,85; в Мезенском - от 0,47 до 0,90, при среднем 0,67 и в Волго-Уральском - от 0,33 до 0,48, при среднем 0,37. Средние значения $\mathrm{Ca} / \mathrm{Cl}$ отношения изменяются от 0,12 до 0,32 в первом случае, составляя 0,07 - во втором, 0,14 - в третьем и 0,32 в четвертом. Наиболее близки по составу и степени метаморфизации (катагенетических изменений) рассолы Лено-Тунгусского и Волго-Уральского бассейнов.

Статистический анализ гидрогеохимических данных позволил установить характеристики регионального гидрогеохимического фона и аномалий в пределах вендских резервуаров. Рассолы фонового состава характеризуются хлоридным кальциево-натриевым составом с величиной общей минерализации 323 г/дм³ Содержание $\mathrm{HCO}_{3}{ }^{-}$не превышает 0,25 г/дм ${ }^{3}, \mathrm{SO}_{4}{ }^{2-}-0,6$ г/дм ${ }^{3}, \mathrm{Na}^{+}-45,1$ г/дм ${ }^{3}, \mathrm{Ca}^{2+}-$ 58,3 г/дм ${ }^{3}, \mathrm{Mg}^{2+}-10,1$ г/дм ${ }^{3}, \mathrm{~K}^{+}-6,1$ г/дм³ $\mathrm{Sr}^{2+}$ - не более 1,84 г/дм ${ }^{3}, \mathrm{Br}^{-}$не выше 3,65 г/дм ${ }^{3}, \mathrm{NH}_{4}^{+}$не более 0,23 г/дм ${ }^{3}$ и т.д.

Среди микрокомпонентов наибольшие концентрации йода > 0,03 г/дм ${ }^{3}$ установлены на Елохтинской, Пайгинской, Собинской, Среднеботуобинской, ТаасЮряхской и Бюк-Танарской и других площадях; брома > 3,6 г/дм ${ }^{3}$ на Аянской, Братской, Верхнеджелиндинской, Верхнечонской, Дулисьминской, Криволукской, Марковской и других площадях; бора > 0,04 г/дм³ встречены в рассолах на Аянской, Братской, Вакунайской, Верхоленской, Имбинской, Пайгинской, Седановской, Среднеботуобинской, Юрубченской и других площадях. Среди щелочных элементов концентрации рубидия более 8,7 мг/дм³ установлены на Братской, Ванаварской, Имбинской, Пеледуйской, Седановской, Шаманской и др. площадях; лития > 46,1 
мг/дм ${ }^{3}$ выявлены на Аянской, Балаганкинской, Верхоленской, Енгидинской, Ковыктинской, Седановской, Шамановской и других площадях. Среди щелочноземельных элементов значения $\mathrm{Sr}$ более 1,84 г/дм ${ }^{3}$ отмечены в рассолах на Аянской, Большеокинской, Братской, Верхневилючанской, Касаткинской, Криволукской, Марковской, Шамановской, Ярактинской и др. площадях. В зону повышенных концентраций (> 43,0 мг/дм³) по цинку попадают рассолы Братской, Елохтинской, Собинской, Чамбинской и других площадей. Концентрации марганца > 112,1 мг/дм ${ }^{3}$ отмечены в рассолах Балаганкинской, Братской, Бюк-Тарской, Верхнетирской, Дулисьминской, Кийской, Криволукской, Среднеботуобинской Ярактинской и др. площадей. Высокие значения аммония более 232,0 мг/дм³ выявлены на Аянской, Братской, Верхнекатангской, Дулисьминской, Катангской, Криволукской, Собинской, Тутурской, Ярской и других площадях.

\section{Латеральная гидрогеохимическая зональность}

В зонах сочленения Сибирской платформы со складчатыми структурами распространены разновозрастные хлоридные натриевые рассолы выщелачивания каменной соли. С удалением от ее периферии они сменяются полосой распространения хлоридных рассолов смешанного катионного состава с преобладанием натрия, которые, в свою очередь, переходят в рассолы смешанного состава с преобладанием кальция. Хлоридные кальциево-магниевые рассолы имеют локальное распространение в разных горизонтах вендского комплекса. В непском и вилючанском горизонтах они установлены в северной части Ангаро-Ленской ступени на юге Сибирской платформы (Купская площадь). В рассолах тирского и нижнеданиловского горизонтов они имеют большее распространение и выявлены на Большетирской, Грузновской, Купской и Озерной площадях.

Площадная региональная гидрогеохимическая зональность, обуславливается местоположением внешних (краевых) и внутриплатформенных зон (областей) питания 
и разгрузки. В изученных горизонтах вендского возраста могут быть выделены три зоны.

Первая зона (с минерализацией подземных вод до 150 г/дм³ ) протягивается узкой полосой вдоль окраин платформы в местах выходов терригенного комплекса на дневную поверхность и в непосредственной близости от них. На участках, где терригенные отложения погружаются на большие глубины, минерализация подземных рассолов быстро достигает 300 г/дм ${ }^{3}$ и более. В гидродинамическом отношении эта зона соответствует краевой (внешней) области питания (в основном активный режим водообмена). Абсолютные отметки приведенных напоров в ней максимальны и достигают 600-800 м.

Вторая зона (с минерализацией подземных рассолов 150-320 г/дм³) примыкает к первой и протягивается узкой полосой по окраинам платформы. Она характеризуется крепкими хлоридными рассолами выщелачивания солей преимущественно натриевого или кальциево-натриевого состава. В гидродинамическом отношении эта область является переходной от зоны активного водообмена к зоне сильно затрудненного (застойного) режима. Отметки приведенных напоров в ней быстро снижаются до 500300 м.

Третья зона охватывает оставшуюся часть изучаемой территории. Минерализация рассолов терригенного комплекса в этой области повсеместно превышает 320 г/дм³ (предел растворимости галита), т.е. рассолы здесь являются крепкими, весьма крепкими (более 320 г/дм³) и предельно насыщенными хлоридного кальциевого и магниево-кальциевого типов. Режим водообмена в этой зоне сильно затруднен и близок к застойному. Абсолютные отметки приведенных напоров минимальны и снижаются до 200-50 м, иногда до нуля и до минусовых отметок.

Обстановки седиментации, степень метаморфизации (катагенетических изменений) химического состава и генезис рассолов 
Согласно [Мельников, 2009] в непское время в северной и центральной части Сибирской платформы доминировали континентальные обстановки осадконакопления. По ее периферии шло накопление преимущественно терригенных, карбонатнотерригенных осадков. На востоке существовал мелководный морской бассейн с повышенной соленостью. В тирское время наблюдалась обширная трансгрессия моря и участки суши сохранились лишь в северо-западных районах Сибирской платформы. Так в юго-западной части (Байкитская антеклиза, Присаяно-Енисейская синеклиза и Ангаро-Ленская ступень) преобладали обстановки терригенного осадконакопления. В северо-восточном направлении они сменялись первоначально сульфатно-терригеннокарбонатными, галогенно-карбонатными и галогенно-сульфатно-карбонатными в пределах Предпатомского прогиба. В раннеданиловское время на большей части платформы существовал мелководный морской бассейн. В центральной части Сибирской платформы разрез представлен глинистыми доломитами. В северных районах преобладал глинисто-известковый состав осадков. В южной части доминировали обстановки сульфатно-карбонатного и галогенно-карбонатного осадконакопления. Максимальные мощности каменной соли установлены в центральной части Присаяно-Енисейской синеклизы. В среднеданиловское время участи суши сохранились в южных и юго-западных районах платформы. В северной части формировались глинисто-известковистые породы. В центральной части бассейна разрез меняется на сульфатно-доломитовые и на галогенно-доломитовые породы на юге. Наибольшие прослои каменной соли установлены в пределах Предпатомского прогиба и Присаяно-Енисейской синеклизы. В позднеданиловское время обстановки морского осадконакопления доминировали на территории всей Сибирской платформы. Глубина моря была небольшой. На всей территории формировались известняки и доломиты, что позволяет говорить о солености морского бассейна до 80 г/дм³ [Валяшко, 1962; Вожов, 2006; Мельников, 2009]. В конце венда существовала серия зон 
соленакопления, где величина общей минерализации рапы достигала стадии садки сильвина и карналлита (до 430-470 г/дм³). Солеродные бассейны имевшие максимальную площадь развития в раннем-среднем кембрии [Писарчик и др., 1975] стали источниками нескольких фаз гравитационного опускания рассолов в горизонты венда. За счет процессов инфильтрации метеорных вод происходил промыв рассолоносных вендских отложений и выравнивание величины общей минерализации. Территория распреснения доходила до барьерного рифа - как естественной границы солеродного бассейна [Сухов и др., 2018].

Сравнительный анализ геохимических особенностей рассолов показал, что по $\mathrm{rNa} / \mathrm{rCl}, \mathrm{Cl} / \mathrm{Br}, \mathrm{Ca} / \mathrm{Cl}$ отношениям и $\mathrm{S}$ все изученные воды обособляются в две генетические группы (рис. 7). Первая (группа I) представлена разновозрастными инфильтрогенными рассолами преимущественно хлоридного натриевого состава, выявленными по периферии бассейна. Они характеризуются величиной общей минерализации до 320 г/дм³ , повышенным $\mathrm{rNa} / \mathrm{rCl}$ (до 1,55), $\mathrm{Cl} / \mathrm{Br}$ (до 2512) и $\mathrm{Ca} / \mathrm{Cl}$ (в среднем 0,3) отношениями. Средние величины интегрированного показателя метаморфизации рассолов S составляют от 50 до 200. Их состав формировался преимущественно за счет процессов растворения наиболее растворимых минералов пород - галита, гипса и карбонатов [Басков, 1967; Пиннекер, 1977; Букаты, Шварцев, 1983]. Они распространены узкой полосой вдоль окраины платформы. Их состав и величины основных генетических коэффициентов близки к современным рассолам выщелачивания каменной соли в пределах солянокупольных структур АнабароХатангского бассейна, где существует связь с поверхностью [Новиков, Сухорукова, 2012; Черных, Новиков, 2018; Черных, Новиков, 2020]. На глубинах более километра происходят изменения в их химическом составе, а именно снижение сульфатности и рост относительной концентрации щелочноземельных металлов, брома и других галогенных и галофильных микрокомпонентов. 
Ко второй (группе II) с наибольшей степенью метаморфизации относятся седиментогенно-инфильтрогенно-метаморфические крепкие рассолы преимущественно хлоридного кальциевого и кальциево-магниевого состава с величиной общей минерализации, превышающей 350 г/дм³. Для них характерны низкие значения $\mathrm{rNa} / \mathrm{rCl}$ (в среднем 0,3), $\mathrm{Cl} / \mathrm{Br}$ (до 100), повышенные значения $\mathrm{Ca} / \mathrm{Cl}$ (в среднем 0,4) коэффициентов. Значения показателя S составляют более 250. Своим происхождением они обязаны нисходящей фильтрацией кембрийских рассолов в диагенезе (гравитационный эффект) и последующей метаморфизацией их состава при доломитизации известняков по широко известной реакции Мариньяка [Гуревич, 1963; Валяшко и др., 1965; Лебедев, 1966; Валяшко, Власова, 1971]. Другой механизм их формирования связан с взаимодействием рассолов с кальцийсодержащими алюмосиликатами и силикатами, что было экспериментально доказано М.Г. Валяшко и Н.К. Власовой в 1975 году [Валяшко, Власова, 1975] и термодинамически в работе С.Л. Шварцева и М.Б. Букаты [Шварцев, Букаты, 1995]. Соотношение натриевокальциевых и кальциевых рассолов по латерали и в разрезе связано с увеличением относительного содержания кальция с ростом общей минерализации. Хлоридные кальциевые рассолы с минерализацией 350-410 г/дм³ доминируют в пределах юговосточной окраины Тунгусского бассейна, в границах северо- западного склона НепскоБотуобинской антеклизы. Рассолы только хлоридного натриево-кальциевого состава распространены в западной части Сибирской платформы.

Помимо вышеуказанных, одним из наиболее важных факторов формирования химического состава седиментогенно-инфильтрогенно-метаморфических рассолов является трапповый магматизм и сопровождающая его гидротермальная деятельность в пермо-триасовое время [Конторович и др., 1996б; Конторович и др., 1996в; Конторович и др., 1997; Конторович, Хоменко, 2001; Конторович и др., 2001; Конторович и др., 2003]. Исследования А.Э. Конторовича, А.Л. Павлова, Г.А. Третьякова и А.В. Хоменко 
по моделированию взаимодействий в системе «сульфатно-карбонатные породы - вода углеводороды» [Конторович и др., 1996в; Конторович и др., 2001] показали, что главными активными компонентами в системе являются ангидрит и углеводороды, а сера выступает в качестве окислителя. При недостатке ангидрита в продуктах реакций главными компонентами в газовой фазе являются $\mathrm{CH}_{4}, \mathrm{CO}_{2}$, и $\mathrm{H}_{2} \mathrm{~S}$ при температурах 100-300 ㄷ․ При дальнейшем повышении температуры содержание метана уменьшается, а диоксида углерода увеличивается. При температурах свыше $500{ }^{\circ} \mathrm{C}$ в газах появляется COS. В нефти в заметных количествах появляются меркаптаны, максимальная концентрация которых наблюдается при температурах до $400{ }^{\circ} \mathrm{C}$. В твердой фазе разрушаются доломит и ангидрит и новообразуются кальцит и периклаз. В породах появляется самородная сера, содержание которой растет с повышением температуры. При избытке ангидрита метан и другие углеводородные газы в продуктах реакций отсутствуют во всем интервале температур. Основными компонентами являются $\mathrm{CO}_{2}$ и $\mathrm{H}_{2} \mathrm{~S}$. Содержание компонентов в твердой фазе меняется по предыдущей схеме, но ангидрит в тех или иных количествах присутствует во всем интервале температур. Содержание меркаптанов в нефтях очень низкие.

Влияние интрузий наиболее ярко отражается в составе водорастворенных газов (ВРГ). Так, если в зоне влияния интрузии до 100 м в составе ВРГ доминирует углекислый газ с содержанием более 90 об. \%, при содержании метана до 5 об. \%, то на расстоянии 250 м концентрации $\mathrm{CO}_{2}$ падают до 30 об. \%, а $\mathrm{CH}_{4}$ растут до 60-70 об. \%. Схожие тенденции установлены для всего ряда гомологов от этана до гексана. Например, ВРГ с содержанием в составе $\mathrm{CO}_{2}>90$ об.\% выявлены на Восточно- и Западно-Ногинской, Нижне-Тунгусской и Таначинской площадях. Установлена тенденция снижения его содержаний с глубиной и роста концентраций гелия до 0,400,52 об.\% в интервале 3250-3500 м в пределах Курейской синеклизы [Novikov et al., 
2019; Новиков и др., 2020]. Влияние интрузивного тела на преобразование состава водорастворенных газов нивелируется на расстоянии около 400 м.

В составе свободных газов залежей сохраняются идентичные тенденции, установленные ранее в работах А.Э. Конторовича с сотрудниками [Конторович и др., 1996б]. Траппы двояко повлияли на нефтегазоносность: с одной стороны - сильный прогрев осадочных пород (более $400{ }^{\circ} \mathrm{C}$ ) привел к почти полному уничтожению существующих УВ залежей, с другой стороны - нефтематеринские толщи попали в главную зону нефтегазообразования, что существенно увеличило стратиграфический диапазон нефтегазогенерации [Конторович и др., 2001] и привело к генерации углеводородов с формированием вторичных залежей [Конторович и др., 1996б; Конторович, Хоменко, 2001]. Также внедрившиеся траппы оказали существенное воздействие на коллекторские свойства продуктивного горизонта - качество и выдержанность, активизировав процессы вторичных изменений в карбонатных породах. Высокие температуры, по мере удаленности траппа от продуктивного горизонта, оказали значительное влияние на изменение фазового состава сформированных на момент внедрения пластовых интрузий залежей [Кузнецова и др., 2014]. Так при диапазоне температур $400-650{ }^{\circ} \mathrm{C}$ сохраняется менее 10 \% залежей с преобладанием в составе неорганических газов таких как $\mathrm{CO}_{2}$, CO, COS. При температурах $400-300^{\circ} \mathrm{C}$ залежи также будут газовыми с преобладанием углекислого газа. Возможно наличие маломощной нефтяной оторочки тяжелых меркаптановых нефтей. При температурах $300-100{ }^{\circ} \mathrm{C}$ сохранится до 70 \% залежей. Залежи будут газонефтяные, преимущественно метановые с незначительным количеством конденсатных и неуглеводородных газов [Конторович и др., 2001].

Выявленных закономерности по изменению состава водорастворенных и свободных газов также подтверждаются анализом газожидкостных включений (ГЖВ). Установлено, что в пределах районов с высокой насыщенностью разреза траппами, в их 
составе доминирует углекислый газ (Тунгусская синеклиза, Байкитская антеклиза и др.) [Гришина и др., 1987; Grishina et. al., 1992; Гришина, Конторович, 1995; Grishina et. al., 1991; Grishina et. al., 1993; Grishina et. al., 1997; Grishina et. al., 1998; Гришина и др., 2008]. В зонах отсутствия магматических интрузий Непского месторождения калийных солей в составе ГЖВ начинает доминировать метан [Гришина и др., 1987].

Тепловое воздействие траппов следует считать главной причиной метаморфизма рассеянного органического вещества [Конторович и др., 1977], наиболее высокой минерализации и катагенетических изменений состава рассолов Сибирской платформы [Букаты, 1999], а также галитизации песчаников вендских отложений [Вожов, 2006]. Так, например, наиболее близкие к состоянию предельного насыщения к галиту рассолы установлены в зоне наибольшего засолонения коллекторов, а также вблизи разломов или границ усольского траппового силла на Ярактинской площади [Букаты и др., 1981]. Снижение соленасыщенности ярактинских песчаников в направлении от верхнего пласта (3-7, редко 13\%) к нижнему (0,7-3, редко 10 \%) свидетельствует об осаждении солей при нисходящей фильтрации высококонцентрированных рассолов по разрывным и приинтрузивным трещинным зонам (вероятные палеогидроразрывы) [Вожов, 2006]. Такое распределение галитонасыщения находится в хорошем соответствии с понижением пластовых давлений и коэффициентов аномальности от осинского и усть-кутского (26-34 МПа и 1,2) горизонтов к верхнетирскому и ярактинскому (24-27 МПа и 0,88-1) [Вожов, 1987]. Под воздействием магматического и гидротермального тепла палеотемпературы в осинском горизонте повышались до 150$800{ }^{\circ} \mathrm{C}$ (в зависимости от расстояния до интрузии), а в залегающем на 360-420 м глубже ярактинском - до 160 ㄷ․ Повышение палеодавлений до 100 МПа [Феоктистов, 1978] и высокотемпературное расширение флюидов стали причиной палеогидроразрывов и конвективных нисходяще-восходящих перетоков флюидов, облегченных в результате понизившийся вязкости в высокоградиентом палеотермобарическом и 
палеогидрогеохимическом полях. Инверсионный палеогеотермический градиент составлял от 10 до $100^{\circ} \mathrm{C}$. При нисходящем перемещении рассолов из высокотемпературного осинского горизонта в холодных ярактинский и при смешивании рассолов разной минерализации в обоих горизонтах осаждался галит [Вожов, 2006]. Следует отметить, что широко известная проблема засолонения коллекторов естественное следствие предельной метаморфизации химического состава седиментационных рассолов в ходе их катагенетической геохимической эволюции.

Таким образом, уровень метаморфизации (катагенетических изменений) химического состава рассолов вендских отложений возрастает от наименее минерализованных $\mathrm{Cl} \mathrm{Na}$ до крепких $\mathrm{Cl} \mathrm{Ca}$ и $\mathrm{Ca}-\mathrm{Mg}$ рассолов. Совместное рассмотрение $\mathrm{rNa} / \mathrm{rCl}, \mathrm{Cl} / \mathrm{Br}, \mathrm{Ca} / \mathrm{Cl}$ отношений вместе с интегрированным показателем S подтверждает этот факт.

\section{ЗАКЛЮЧЕНИЕ}

Резюмируя вышесказанное можно сделать следующие выводы:

1) Рассолы вендских отложений Сибирской платформы характеризуются преимущественно хлоридным натриево-кальциевым и кальциевым составом с величиной общей минерализации от 280 до 400 г/дм³. Преобладают кислые и слабокислые рассолы $(\mathrm{pH}=3,0-5,5)$ с вариацией значений $\mathrm{pH}$ от 3,0 до 7,0. Значения окислительно-восстановительного потенциала Eh варьируют от резко восстановительных -440 мВ до окислительных +130 мВ геохимических обстановок, при доминировании восстановительных с $\mathrm{Eh}=-176$ мВ. Несмотря на локальную изменчивость гидрогеохимического поля вендских горизонтов, наблюдается отчетливая латеральная зональность состава рассолов от хлоридного натриевого по периферии бассейна до хлоридного кальциевого в его внутренних районах.

2) Во время предвилючанского, преднепского, предтирского и предданиловского перерывов в осадконакоплении в изучаемые отложения проникали инфильтрационные 
воды. Можно предположить два этапа поступления рассолов в вендские горизонты. Первый связан с несколькими фазами гравитационного опускания рассолов периодов существования на платформе кембрийских солеродных бассейнов, а второй сопровождал процессы траппового магматизма в пермо-триасовое время.

3) Сравнительный анализ геохимических особенностей рассолов показал, что по $\mathrm{rNa} / \mathrm{rCl}, \mathrm{Cl} / \mathrm{Br}, \mathrm{Ca} / \mathrm{Cl}$ отношениям и $\mathrm{S}$ они обособляются в две генетические группы. Первая (группа I) включает разновозрастные инфильтрогенные рассолы преимущественно хлоридного натриевого состава, развитые во внешних областях питания бассейна по периферии Сибирской платформы. Они характеризуются величиной общей минерализации до 320 г/дм³ , повышенным rNa/rCl (до 1,55), Cl/Br (до 2512) и $\mathrm{Ca} / \mathrm{Cl}$ (в среднем 0,3) отношениями. Средние величины интегрированного показателя метаморфизации рассолов S составляют от 50 до 200. Вторая (группа II) объединяет седиментогенно-инфильтрогенно-метаморфические крепкие рассолы преимущественно хлоридного кальциевого и кальциево-магниевого состава с величиной общей минерализации, превышающей 350 г/дм³. Для них характерны низкие значения $\mathrm{rNa} / \mathrm{rCl}$ (в среднем 0,3), $\mathrm{Cl} / \mathrm{Br}$ (до 100) и повышенные значения $\mathrm{Ca} / \mathrm{Cl}$ (в среднем 0,4) коэффициентов. Величины показателя S составаляют более 250. Формирование их состава проходило в два этапа. На первом происходило несколько фаз гравитационного опускания рассолов кембрийских солеродных бассейнов в вендские горизонты. На втором этапе в пермо-триасовое время происходило внедрение траппов, сопровождающееся гидротермальной деятельностью, что привело к значительному изменению рассоловмещающих пород (галитизации песчаников - засолонению коллекторов), значительному росту общей минерализации рассолов и катагенетическим изменениям их состава. 
Авторы выражают искреннюю благодарность академику А.Э. Конторовичу за идейное вдохновение и ценные замечания, высказанные в процессе подготовки рукописи.

Исследования проводились при финансовой поддержке проекта ФНИ № 03312019-0025 «Геохимия, генезис и механизмы формирования состава подземных вод арктических районов осадочных бассейнов Сибири» и Российского фонда фундаментальных исследований в рамках научного проекта № 18-05-70074 «Ресурсы Арктики».

\section{ЛИТЕРАТУРА}

Алексеев С.В., Алексеева Л.П., Борисов В.Н., Шоуакар-Сташ О., Фрейп Ш., Шабо Ф., Кононов А.М. Изотопный состав (H, O, Cl, Sr) подземных рассолов Сибирской платформы // Геология и геофизика. 2007, т. 48, № 3, с. 291-304.

Алексеева Л.П., Алексеев С.В. Геохимия подземных льдов, соленых вод и рассолов западной Якутии. Н.: Академическое издательство «ГЕО», 2019, 214 с.

Анциферов А.С., Артеменко А.С., Зехова О.В., Золотов А.Н., Ильин Г.Н., Молева Т.А., Павлов В.В., Пензина Г.М., Ржечицкий Ю. П., Яценко И.Н. Гидрогеология Иркутского нефтегазоносного бассейна. Восточно-Сибирское книжное издательство, 1971,124 c.

Анциферов А.С., Бакин В.Е., Варламов И.П., Вожов В.И., Воробьев В.Н., Гольберт А.В., Гребенюк В.В., Гришин М.П., Гурова Т.И., Дробот Д.И., Конторович А.Э., Кузнецов В.Л., Лебедев В.М., Левченко И.Г., Мандельбаум М.М., Мельников Н.В., Микуленко К.И., Назимков Г.Д., Накаряков В.Д., Полякова И.Д., Рыбьяков Б.Л., Савицкий В.Е., Самсонов В.В., Стасова О.Ф., Старосельцев В.С., Трофимук А.А., Фотиади Э.Э., Хоменко А.В. Геология нефти и газа Сибирской платформы. М.: Недра, 1981. 552 c. 
Анциферов А.С. Гидрогеология древнейших нефтегазоносных толщ Сибирской платформы. М.: Недра, 1989. 176 с.

Афанасьев Т.П., Ахмедсфаин У.М., Бабинец А.Е., Баучидзе А.Е., Духанина В.И., Ефимов А.И., Зайцев Г.Н., Зайцев И.Н., Калмыков А.Ф., Кенесарин Н.А., Куделин Б.И., Маккавеев А.А., Маневская Г.А., Обидин Н.И., Овчинников А.М., Плотников Н.И., Покрышевский О.И., Попов В.Н., Попов И.В., Роговская Н.В., Соколов Д.С., Сидоренко А.В., Толстихин Н.И., Фомин В.М., Чаповский Е.Г., Чуринов М.В., Щеголев Д.И., Иванилова Р.Ф., Кауров В.Ф., Куренной В.В., Пиннекер Е.В., Ткачук В.Г., Трофимук П.И., Тумольский Л.М. Гидрогеология СССР. Том ХІХ. Иркутская область. М.: Недра, 1968, 496 с.

Афанасьев Т.П., Ахмедсфаин У.М., Бабинец А.Е., Баучидзе А.Е., Духанина В.И., Ефимов А.И., Зайцев Г.Н., Зайцев И.Н., Калмыклв А.Ф., Кенесарин Н.А., Маневская Г.А., Плотников Н.И., Покрышевский О.И., Попов И.В., Роговская Н.В., Сидоренко А.В., Соколов Д.С., Толстихин Н.И., Фомин В.М.. Чаповский Е.Г., Чуринов М.В., Басков Е.А., Белякова Е.Е., Диюк Н.И., Зайцев И.К., Зуев А.В., Капустина М.Г., Шуб В.А. Гидрогеология СССР. Том XVIII. Красноярский край и Тувинская АССР. М.: Недра, 1972, 479 с.

Басков Е.А. Подземные минеральные воды и палеогидрогеология Восточно-Сибирской артезианской области. Автореф. докт. дис. Л., 1967, 62 с.

Басков Е.А. Главные черты распространения и формирования основных типов подземных рассолов Сибирской платформы // Подземные рассолы СССР. Труды ВСЕГЕИ. 1976, т.246, с. 61-75.

Букаты М.Б., Вожов В.И., Горохова Г.А., Рахленко Е.З., Шварцев С.Л. Причины засоления нефтегазоносных коллекторов на юге Сибирской платформы // Геология и геофизика. 1981, № 9, с. 17-27. 
Букаты М.Б., Шварцев С.Л. Равновесие высокоминерализованных подземных рассолов с эвапоритовыми минералами // Советская геология. 1983, № 8, с. 114-123.

Букаты М.Б. Равновесие подземных рассолов Тунгусского бассейна с минералами эвапоритовых и терригенных фаций // Геология и геофизика. 1999, т. 40, № 5, с. 750763.

Бурштейн Л.М., Конторович А.Э., Лившиц В.Р., Моисеев С.А., Ярославцева Е.С. Вероятностная оценка перспективных ресурсов гелия центральных и южных районов Лено-Тунгусской нефтегазоносной провинции // Геология и геофизика. 2020, т. 61, № 3, c. $400-408$.

Валяшко М.Г. Геохимические закономерности формирования месторождений калийных солей. М.: Издательство МГУ, 1962, 403 с.

Валяшко М.Г., Поливанова А.И., Жеребцова И.К., Метких Б.И. Геохимия и генезис рассолов Иркутского амфитеатра. М.: Наука, 1965, 159 с.

Валяшко М.Г., Власова М.К. Экспериментальное исследование взаимодействия метаморфизованных морских рассолов с карбонатом кальция // Геохимия. 1971, № 5, с. 610-615.

Валяшко М.Г., Власова М.К. Устойчивость солей магния в растворах морского происхождения и ее гидрогеохимическое значение // Вестник МГУ. Серия 4, Геология. 1975, № 4, c. 16-27.

Вожов В.И. Подземные воды Тунгусского бассейна. М.: Недра, 1977, 80 с.

Вожов В.И. Гидрогеологические условия месторождения нефти и газа Сибирской платформы. М.: Недра, 1987, 204 с.

Вожов В.И. Подземные воды и гидроминеральное сырье Лено-Тунгусской нефтегазоносной провинции. Новосибирск: СНИИГГиМС, 2006, 209 с. 
Гришина С.Н., Дюбесси Ж., Конторович А.Э., Кудрина Т.Р. Включения в солях кембрия Бахтинского мегавыступа как показатель условий формирования и сохранности залежей нефти и газа // Геология и геофизика. 1987, №12, с. 31-38.

Гришина С.Н., Конторович А.Э. Включения в галитах из карбонатно-эвапоритовых нефтегазоносных отложений кембрия Сибирской платформы как индикаторы преобразований пород и нафтидов при внедрении интрузий долеритов // Результаты работ по Межвед. регион. науч. прогр. "Поиск" за 1992-1993 гг. Новосибирск. 1995, Ч. 1, c. $160-166$.

Гришина С.Н., Полозов А.Г., Конторович А.Э., Пиронон Ж. Включения нафтидов в галите Непского калийного месторождения // Дегазация Земли: геодинамика, геофлюиды, нефть, газ и их парагенезы: Материалы Всерос. конф. Москва: ГЕОС. 2008, c. $138-140$.

Гуревич В.И. К дискуссии о происхождении хлоридных кальциевых рассолов // Советская геология. 1963, № 8, с. 150-157.

Ильина Е.В., Любомиров Б.Н., Тычино Н.Я. Подземные воды и газы Сибирской платформы. Л.: Гостоптехиздат. Ленинградское отделение, 1962, 301 с.

Каширцев В.А., Парфенова Т.М., Моисеев С.А., Черных А.В., Новиков Д.А., Бурштейн Л.М., Долженко К.В., Рогов В.И., Мельник Д.С., Зуева И.Н., Чалая О.Н. Прямые признаки нефтегазоносности и нефтематеринские отложения Суханского осадочного бассейна Сибирской платформы // Геология и геофизика. 2019, т. 60, № 10, c. $1472-1487$.

Конторович А.Э., Мельников Н.В., Старосельцев В.С. Нефтегазоносные провинции и области Сибирской платформы // Геология и нефтегазоносность Сибирской платформы: Тр. СНИИГГиМС; Вып. 222. - Новосибирск, 1975, с. 4-21.

Конторович А.Э., Мельников Н.В., Старосельцев В.С. Нефтегазогеологическое районирование Сибирской платформы // Геология нефти и газа. 1976, № 2, ч. 6-16. 
Конторович А.Э., Кащенко С.А., Зуева Т.Н., Ивлев Н.Ф., Казаринов В.В., Ларичев А.И., Маркова Л.Г., Соболев П.Н. Перспективы нефтеносности и газоносности вендских и нижне-среднепалеозойских отложений Сибирской платформы // Геология, условия формирования и методика разведки месторождений нефти и газа в палеозойских и мезозойских отложениях Сибирской платформы: Сб. науч. тр. Новосибирск: СНИИГГиМС, 1978, с. 4-25.

Конторович А.Э., Сурков В.С., Трофимук А.А. Геология нефти и газа Сибирской платформы. М.: Недра, 1981, 552 с.

Конторович А.Э., Трофимук А.А., Башарин А.К., Беляев С.Ю., Фрадкин Г.С. Глобальные закономерности нефтегазоносности докембрия Земли // Геология и геофизика. 1996, т. 37, № 8, с. 6-42. (а)

Конторович А.Э., Филипцов Ю.А., Битнер А.К., Стасова О.Ф., Хоменко А.В. Кембрийские газы, нефти и конденсаты на Сибирской платформе в районах интенсивного развития траппового магматизма // Геохимия. 1996, № 9, с. 875-883. (б)

Конторович А.Э., Павлов А.Л., Третьяков Г.А., Хоменко А.В. Физико-химическое моделирование равновесий в системе «карбонат-эвапоритовые породы-водауглеводороды» при контактовом метаморфизме и катагенезе // Геохимия. 1996, №7, с. 589-611. (в)

Конторович А.Э., Павлов А.Л., Хоменко А.В., Третьяков Г.А. Физико-химические условия графитизации углеводородсодержащих пород (на примере запада Сибирской платформы). // Геохимия. 1997, № 6, с. 563-570.

Конторович А.Э., Хоменко А.В. Теоретические основы прогноза нефтегазоносности осадочных бассейнов с интенсивным проявлением траппового магматизма // Геология и геофизика. 2001, Т.42, № 11-12, с.1764-1773.

Конторович А.Э., Хоменко А.В., Павлов А.Л., Жидкова Л.В., Кузнецова Е.Н., Гордеева А.О. Нефтегазовые системы в условиях аномально высоких температур // 
Проблемы геологии континентов и океанов. Доклады Российских ученых-участников 31-го МГК. Магадан: Кортис, 2001, с. 237-246.

Конторович А.Э., Павлов А.Л., Хоменко А.В. Трапповый магматизм и его влияние на нефтегазоносность Сибирской платформы // Проблемы нефтегазоносности Сибирской платформы: Материалы науч.-практ. конф. Новосибирск. 2003, с. 84-85.

Кузнецова Е.Н., Гордеева А.О., Константинова Л.Н., Глинских В.Н., Губин И.А. Модели строения месторождений нефти и газа Южно-Тунгусской нефтегазоносной области // Геология нефти и газа. 2014, № 1, с. 91-100.

Лебедев В.И. К седиментационно-диагенетической теории образования хлориднокальциевых вод // Вестник ЛГУ. 1966, № 6, с. 26-41.

Мельников Н.В., Якшин М.С., Шишкин Б.Б., Ефимов А.О., Карлова Г.А., Килина Л.И., Константинова Л.Н., Кочнев Б.Б., Краевский Б.Г., Мельников П.Н., Наговицин К.Е., Постников А.А., Рябкова Л.В., Терлеев А.А., Хабаров Е.М. Стратиграфия нефтегазоносных бассейнов Сибири. Рифей и венд Сибирской платформы и ее складчатого обрамления. Новосибирск: Гео, 2005, 428 с.

Мельников Н.В. Венд-кембрийский соленосный бассейн Сибирской платформы. Новосибирск: СО РАН, 2009, 148 с.

Мельников Н.В. Венд-кембрийский соленосный бассейн Сибирской платформы. (Стратиграфия, история развития). Изд. 2-е, доп. - Новосибирск: СНИИГГиМС, 2018, 177 c.

Мельников Н.В. Детальная стратиграфическая схема вендского нефтегазоносного комплекса Лено-Тунгусской провинции Сибирской платформы (Красноярский край). Новосибирск: СНИИГГиМС, 2020, 88 с.

Новиков Д.А., Сухорукова А.Ф. Высокоминерализованные воды полуострова ЮрюнгТумус // Интерэкспо Гео-Сибирь. 2012, т. 1, № 2, с. 109-113. 
Новиков Д.А., Черных А.В., Юрчик И.И., Дульцев Ф.Ф., Хилько В.А. Гидрогеохимия терригенного комплекса венда Сибирской платформы // Геологическая эволюция взаимодействия воды с горными породами: Материалы третьей Всероссийской научной конференции с междунар. участием. Чита: БНЦ СО РАН. 2018, c. $456-460$.

Новиков Д.А., Гордеева А.О., Черных А.В, Дульцев Ф.Ф., Житова Л.М. Влияние траппового магматизма на геохимию рассолов нефтегазоносных отложений западных районов Курейской синеклизы (Сибирская платформа) // Геология и геофизика. 2020, DOI: $10.15372 / G i G 2020160$.

Павленко В.В., Обухов В.Ф., Бронников В.А., Анциферов А.С., Артеменко А.С. Гидрогеологические показатели нефтегазоносности докембрийских отложений Иркутского бассейна. М.: Недра, 1978, 125 с.

Пиннекер Е.В. Рассолы Ангаро-Ленского бассейна (закономерности размещения, состав, динамика, формирование и использование). М.: Наука, 1966, 332 с.

Пиннекер E.B. Проблемы региональной гидрогеологии (закономерности распространения и формирования подземных вод). М.: Наука, 1977, 196 с.

Писарчик Я.К., Минаева М.А., Русецкая Г.А. Палеогеография Сибирской платформы в кембрии. Л.: Недра, 1975, 195 с.

Решения Четвертого Межведомственного регионального стратиграфического совещания по уточнению и дополнению стратиграфических схем венда и кембрия внутренних районов Сибирской платформы. Новосибирск: СНИИГГиМС, 1989. 64 с.

Самарина В.С. Гидрогеохимия. Л.: Изд.-во Ленингр. Ун-та, 1977, 360 с.

Сидкина Е.С., Новиков Д.А., Шварцев С.Л. Равновесие подземных рассолов западной части Тунгусского артезианского бассейна с минералами вмещающих пород // Вестник Томского государственного университета. 2012, №11 (364), с. 187-192. 
Сухов С.С., Фомин А.М., Моисеев С.А. Палеогеография как инструмент реконструкции кембрийского рифообразования на востоке Северо-Тунгусской нефтегазоносной области: от истории исследований к перспективам // Нефтегазовая геология. Теория и практика. 2018, т. 13, № 3, с. 1-26

Феоктистов Г.Д. Петрология и условия формирования трапповых силлов. Новосибирск: Наука, 1978, 221 с.

Хоментовский В.В., Федоров А.Б., Карлова Г.А. Нижняя граница кембрия во внутренних районах севера Сибирской платформы // Стратиграфия. Геол. Корреляция. 1998, т. 6, № 1, с. 3-11.

Черных А.В., Новиков Д.А. Палеогидрогеология Анабаро-Хатангского бассейна // Известия высших учебных заведений. Нефть и газ. 2018, № 4, с. 27-33.

Черных А.В., Новиков Д.А., Дульцев Ф.Ф., Юрчик И.И., Хилько В.А. Генетические особенности рассолов вендских отложений Сибирской платформы // Подземные воды Востока России: Материалы Всероссийского совещания по подземным водам Востока России (XXII Совещание по подземным водам Сибири и Дальнего Востока с международным участием). Новосибирск: ИПЦ НГУ, 2018, с. 525-531.

Черных А.В., Новиков Д.А. Палеогидрогеохимия нефтегазоносных отложений Анабаро-Хатангского бассейна // Отечественная геология. 2020, №2, с. 81-96.

Шварцев С.Л. Разложение и синтез воды в процессе литогенеза // Геология и геофизика. 1975, № 5, с. 60-69.

Шварцев С.Л., Букаты М.Б. О роли горных пород в формировании крепких рассолов хлоридно-кальциевого типа. // Доклады АН. 1995, т. 342, № 4, с. 530-533.

Шварцев С.Л. Химический состав и изотопы стронция рассолов Тунгусского бассейна в связи с проблемой их формирования // Геология и геофизика. 2000, № 11, с. 11701184. 
Шемин Г.Г. Геология и перспективы нефтегазоносности венда и нижнего кембрия центральных районов Сибирской платформы (Непско-Ботуобинская, Байкитская антеклизы и Катангская седловина). Новосибирск: СО РАН, 2007, 467 с.

Яковлев Ю.А., Башкова С.Е. Гидрогеологические условия додевонских отложений в северо-восточных районах Волго-Уральской нефтегазоносной провинции и сопредельных территориях // Экспозиция Нефть Газ. 2018, № 62, с. 11-16.

Alexeev S., Alexeeva L., Shouakar-Stash O. Strontium isotopic ratio in brines from the north-east of the Angara-Lenskiy artesian basin // E3S Web of Conferences. 2019, v. 98, 12001.

Bottomley D.J., Katz A., Chan L.H., Starinsky A., Couglas M., Clark I.D., Raven K.G. The origin and evolution of Canadian shield brines: evaporation or freezing of seawater? New lithium isotope and geochemical evidence from the Slave Lake craton // Chem. Geol. 1999, v. 155, pp. 295-320.

Frape S.K., Fritz P. Geochemical trends for groundwaters from the Canadian Shield // Saline Water and Gases in Crystalline Rocks (eds. P. Fritz and S. K. Frape). Geol. Assoc. Can. Spec. Pap. 1987, v. 33, pp. 19-38.

Grishina S.N., Dubessy J., Kontorovich A., Pironon J. Metamorphic fluids of evaporite: A case study exemplified by fluid inclusions from Cambrian salt deposits and oil and gas zones intruded by dolerite sills (Siberia, USSR) // Plinius. 1991, № 5, pp. 94-95.

Grishina S.N., Dubessy J., Kontorovich A.E., Pironon J. Inclusions in salt beds resulting from thermal metamorphism by dolerite sills (eastern Siberia, Russia) // European Journal of Mineralogy. 1992, №4, pp. 1187-1202.

Grishina S., Dubessy J., Kontorovich A., Pironon J., Borisova L.S. Evolution of fluids and organic materials during metamorphism by dolerite intrusion in evaporites of the Siberian platform // 7th Meet. Eur. Union Geosci.. Strasbourg: EUG VII. Terra nova. 1993, vol. 5, pp. 639. 
Grishina S., Pironon J., Kontorovich A., Polosov A., Ariskina O. Hydrocarbon inclusion in Cambrian salt deposits of Siberian platform: a clue for oil geochemistry understanding in metamorphic salts // Proceedings of the XIV European current research on fluid inclusions. Nancy, France. 1997, pp. 136-137.

Grishina S.N., Pironon J., Mazurov M.P., Goryainov S.V., Pustilnikov A.M., Fon-DerFlaas G., Guerci A. Organic inclusions in salt. Part 3. Oil and gas inclusions in Cambrian evaporite deposit from East Siberia. A contribution to the understanding of nitrogen generation in evaporates // Organic Geochemistry. 1998, v. 28, № 5, pp. 297-310.

Kharaka Y.K., Maest A.S., Carother W.W., Law L.M., Lamothe P.J., Fries T.L. Geochemistry of metal-rich brines from central Mississippi Salt Dome basin, USA. // Appl. Geochem. 1987, v. 2, pp. 543-561.

Kharaka Y.K., Hanor H.S. Deep fluid in the continents: I. Sedimentary basins. In:Holland, H.D., Turekian, K.K. (Eds.) // Treatise on Geochemistry. 2003, v. 5, pp. 499-540.

Lowenstein T.K., Risacher F. Closed basin brine evolution and the influence of Ca-Cl inflow waters: Death Valley and Bristol Dry Lake California, Qaidam Basin, China, and Salar de Atacama, Chile // Aquat. Geochem. 2009, v. 15, pp. 71-94.

Malov A.I. Brine Formation in the Mezen Syneclise // Water Resources. 2001, v. 28, № 6, pp. $618-623$.

McCaffrey M.A., Lazar B., Holland H.D. The evaporation path of seawater and the coprecipitation of $\mathrm{Br}^{-}$and $\mathrm{K}^{+}$with the halite // Journal of Sedimentary Petrology. 1986, v.57, №5, pp. 928-937.

Möller P., Weise S.M., Althaus E., Bach W., Behr H.J., Borchardt R., Bräuer K., Drescher J., Erzinger J., Faber E., Hansen B.T., Horn E.E., Huenges E., Kämpf H., Kessels W., Kisten T., Landwehr D., Lodemann M., Machon L., Pekdeger A., Pielow H.U., Reutel C., Simon K., Walther J., Weinlich F.H., Zimmer M. Paleofluids and recent 
fluids in the upper continental crust: results from the German continental deep drilling program // J. Geophys. Res. 1997, v. 102 (B8), pp. 18233-18254.

Möller P., Woith H., Dulski P., Lüders V., Erzinger J., Kämpf H., Pekdeger A., Hansen B., Lodemann M., Banks D. Main and trace elements in KTB-VB fluid: composition and hints to its origin // Geofluids. 2005, v. 5, pp. 28-41.

Möller P., Lüders V., De Lucia M. Formation of Rotliegend Ca-Cl brines in the North German Basin compared to analogues in the geological record // Chemical Geology. 2017, v. 459, pp. 32-42.

Novikov D.A., Trifonov N.S. Hydrogeologic Implications of Industrial Effluent Disposal of the Yurubcheno-Tokhomo Field (Siberian Craton, Russia) // Arabian Journal of Geosciences. 2016, v. 9, issue 1, № 63, pp. 1-14.

Novikov D.A., Saraev M.M. Hydrogeochemistry of the Arctic areas of Siberian petroleum basins // Shiyou Kantan Yu Kaifa. 2017, v. 44, issue 5, pp. 737-744.

Novikov D.A. Hydrogeochemistry of the Arctic areas of Siberian petroleum basins // Petroleum Exploration and Development. 2017, v. 44, issue 5, pp. 780-788.

Novikov D.A Genetic classification of subsurface waters and brines of Arctic regions of Siberia // IOP Conference Series: Earth and Environmental Science. 2018, v. 193 (1), №012049.

Novikov D.A., Chernykh A.V., Dultsev F.F. Geochemistry of brines in Vendian deposits of the Siberian platform // IOP Conference Series: Earth and Environmental Science. 2018, v. 193 (1), №012052.

Novikov D.A., Zhitova L.M., Dultsev F.F., Chernykh A.V. Primary data on the impact from trap magmatism on the hydrogeochemistry of brines in the southwestern part of the Kureyka syncline (Siberian Platform) // E3S Web of Conferences. 2019, v. 98, № 08017 
Paces T. Hydrochemical evolution of saline waters from crystalline rocks of the Bohemian Massif (Czechoslovakia) // Saline Water and Gases in Crystalline Rocks (eds. P. Fritz and S. K. Frape). Geol. Assoc. Can. Spec. Pap. 1987, v. 33, pp. 145-156.

Stober I., Bucher K. The upper continental crust, an aquifer and its fluid: hydraulic and chemical data from $4 \mathrm{~km}$ depth in fractured crystalline basement rocks at the KTB test site // Geofluids. 2005, v. 5, pp. 8-19.

Stotler R.L., Frape S.K., Ruskeeniemi T., Ahonen L., Onstott T.C., Hobbs M.Y. Hydrogeochemistry of groundwaters in and below the base of thick permafrost at Lupin, Nunavut, Canada // J. Hydrol. 2009, v. 373, pp. 80-95. 
Рис. 1. Стратиграфическая схема вендских отложений Сибирской платформы [Мельников, 2009]

Рис. 2. Местоположение изученных скважин на тектонической карте венднижнепалеозойского структурного яруса Лено-Тунгусской провинции Сибирской платформы (по [Конторович и др., 2009]) с элементами фациального районирования вендских отложений (по [Мельников, 2009; Мельников, 2018; Мельников, 2020])

1 - скважины; 2 - границы Лено-Тунгусской нефтегазоносной провинции; 3 - фациальные районы: 1 - Ангаро-Ленский, 2 - Нижнеангарский, 3 - Предъенисейский, 4 - БайкитскоКатангский, 5 - Турухано-Бахтинский, 6 - Непско-Ботуобинский, 7 - Предпатомский; 4 граница субъектов РФ; 5 - населенные пункты; 6 - гидросеть; 7 - границы тектонических элементов, 8-16 тектонические элементы: 8-10 положительные - 8 - надпорядковые, 9 - I порядка, 10 - II порядка, 11-14 - отрицательные - 11 - надпорядковые, 12 - 0 порядка, 13 - I порядка, 14 - II порядка; 15-16 - промежуточные - 15 - моноклинали, 16 - седловины, 17 - Ангаро-Ленская ступень (мегамоноклиза). Цифрами на карте обозначены: Положительные структуры: надпорядковые: 1 - Анабарская антеклиза, 2 - Байкитская антеклиза, 3 - Непско-Ботуобинская антеклиза, 4 - Алданская антеклиза; I порядка: 1 - Турухано-Норильский мегавал, 2 - Бахтинско-Кондроминский выступ, 3 Нижнечунканский выступ, 4 - Сунтарский свод, 5 - Мирнинский выступ, 6 - Камовский свод, 7 - Непский свод, 8 - Богучано-Манзинский выступ, 9 - Братский выступ; II порядка: 1 - Мархинское куполовидное поднятие, 2 - Сенгачангдский структурный мыс, 3 - Ейкинский структурный мыс, 4 - Усть-Илимпейский структурный мыс, 5 Наманинский вал, 6 - Юнаринское куполовидное поднятие, 7 - Кондроминское куполовидное поднятие, 8 - Наканновский структурный мыс, 9 - Кербовский структурный мыс, 10 - Верхневилючанское куполовидное поднятие, 11 - Верхнеамнуннаканское куполовидное поднятие, 12 - Верхнеилимпейский структурный мыс, 13 - ЗападноЧуньский структурный мыс, 14 - Джеюктинский выступ, 15 - Усть-Бирюкский вал, 16 Умоткинский структурный мыс, 17 - Лакурский структурный мыс, 18 - Алтыбский структурный мыс, 19 - Собинско-Тэтэрский выступ, 20 - Чадобецкое куполовидное поднятие, 21 - Ильбокичский структурный мыс, 22 - Чичиканское куполовидное поднятие, 23 - Среднечуньское куполовидное поднятие, 24 - Берямбинское куполовидное поднятие, 25 - Араканское куполовидное поднятие, 26 - Усть-Кутское куполовидное поднятие; Отрицательные структуры: Надпорядковые: 1 - Курейская синеклиза, 2 Вилюйская гемисинеклиза, 3 - Присаяно-Енисейская синеклиза, 4 - Предпатомский региональный прогиб; 0 порядка: 1 - Туринская мегавпадина; I порядка: 1 - Вивинская впадина, 2 - Тюкянская полувпадина, 5 - Ыгыаттинская впадина, 4 - Кемпендяйская впадина, 5 - Нюйско-Джербинская впадина, 6 - Березовская впадина, 7 - Катская впадина, 8 - Мурско-Чуньская впадина, 9 - Долгомостовская впадина; II порядка: 1 - Караульная котловина, 2 - Тембенчинский прогиб, 3 - Фатьяниховский структурный залив, 4 Туруканская котловина, 5 - Верхнетурунская котловина, 6 - Сарсанская котловина, 7 Кочумдэкская котловина, 8 - Восточно-Ыгыаттинская котловина, 9 - СевероБотомоютская котловина, 10 - Южно-Ботомоютская котловина, 11- Конандинский структурный залив, 12 - Биромбинская котловина, 13 - Верхнетаймуринская котловина, 14 - Мурбайская котловина, 15 - Черендейская котловина, 16 - Вильминская котловина, 17 - 
Усть-Пеледуйская котловина, 18 - Верхнеэринская котловина, 19 - Яркинский структурный залив, 20 - Среднеиркинеевский структурный залив, 21 - Казачинский прогиб; Промежуточные структуры: I - Сюгджерская мезоседловина, II - МархиноЧуньская мегамоноклиналь, III - Катангская седловина, IV - Ангаро-Ленская ступень (мегамоноклиза), V - Ангаро-Ленская моноклиналь.

Рис. 3. Диаграмма Пайпера состава подземных рассолов вендских отложений Сибирской платформы

Химические типы хлоридных рассолов (по С.А. Щукареву): 1 - натриевый; 2 - с преобладанием катионов натрия; 3 - с преобладанием катионов кальция и натрия; 4 кальциевый; 5 - с преобладанием катионов кальция и магния.

Рис. 4. Карта общей минерализации и химического состава рассолов вилючанского и непского горизонтов

1 - скважины; 2 - изоминеры, г/дм³; 3 - зона отсутствия отложений непского горизонта; 4 - граница Лено-Тунгусской нефтегазоносной провинции; 5 - границы: а) Российской Федерации, б) субъектов РФ; 6 - населенные пункты; 7 - гидросеть. Химические типы хлоридных рассолов (по С.А. Щукареву): I - натриевый; II - с преобладанием катионов натрия; III - с преобладанием катионов кальция и натрия; IV - кальциевый; V - c преобладанием катионов кальция и магния.

Рис. 5. Карта общей минерализации и химического состава рассолов тирского и нижнеданиловского горизонтов

Условные обозначения - см. рис. 4.

Рис. 6. Зависимость содержаний Na (а), K (б), Ca (в) и Mg (г) от концентрации Cl в рассолах вендских отложений Сибирской платформы

Тренды химических типов хлоридных рассолов: I - натриевый; II - с преобладанием катионов натрия; III - с преобладанием катионов кальция и натрия; IV - кальциевый; V - c преобладанием катионов кальция и магния.

Рис. 7. Изменение отношений $\mathrm{rNa} / \mathrm{rCl}$ (а), $\mathrm{Cl} / \mathrm{Br}$ (б), $\mathrm{Ca} / \mathrm{Cl}$ (в) и степени метаморфизации S (г) (катагенетических изменений) подземных рассолов вендских отложений Сибирской платформы в зависимости от величины их общей минерализации

Стрелкой показано направление метаморфизации химического состава рассолов. 
Таблица 1.

Гидрогеохимическая характеристика региональных горизонтов венда Сибирской платформы

\begin{tabular}{|c|c|c|c|c|c|}
\hline \multirow{2}{*}{ Элемент } & \multirow{2}{*}{ Ед.изм. } & \multicolumn{4}{|c|}{ Региональные горизонты } \\
\hline & & Даниловский & Тирский & Непский & Вилючанский \\
\hline \multicolumn{6}{|c|}{ Состав подземных вод } \\
\hline $\mathrm{HCO}_{3}^{-}$ & мг/дм ${ }^{3}$ & $1,4-5000(607,2)$ & $2-1830(229,3)$ & $\begin{array}{l}6-2440 \\
(262,3)\end{array}$ & $12-290(101,5)$ \\
\hline $\mathrm{SO}_{4}{ }^{2-}$ & - ” - & $4-5498(558,3)$ & $0,1-8723(572,8)$ & $\begin{array}{c}5-16000 \\
(648,5)\end{array}$ & $\begin{array}{l}0,4-415 \\
(141,8)\end{array}$ \\
\hline $\mathrm{Cl}^{-}$ & г/дм ${ }^{3}$ & $0,4-354,1(211,2)$ & $\begin{array}{c}10,2-410,6 \\
(203,3)\end{array}$ & $\begin{array}{c}5,9-291,2 \\
(199,1)\end{array}$ & $\begin{array}{c}173,7-257,7 \\
(220,6)\end{array}$ \\
\hline $\mathrm{Br}^{-}$ & $-”-$ & $0,08-10,7(3,7)$ & $0,004-11,1(3,6)$ & $\begin{array}{c}0,003-10,7 \\
(3,6)\end{array}$ & $0,2-6,2(3,1)$ \\
\hline $\mathrm{I}^{-}$ & мг/дм ${ }^{3}$ & $0,01-144(15,8)$ & $0,1-316(29)$ & $\begin{array}{c}0,1-2200 \\
(40,8)\end{array}$ & $\begin{array}{c}2,5-105,5 \\
(29,8)\end{array}$ \\
\hline $\mathrm{F}^{-}$ & $-”-$ & 1,9-33,5 $(17,1)$ & $0,4-19(9,1)$ & $\begin{array}{c}0,3-125 \\
(18,2)\end{array}$ & - \\
\hline $\mathrm{Na}^{+}$ & г/дм ${ }^{3}$ & $0,01-125,2(40,1)$ & $2-125,4(47,8)$ & $\begin{array}{c}1-146,4 \\
(45,7)\end{array}$ & $12,2-85,6(36,9)$ \\
\hline $\mathrm{Ca}^{2+}$ & $-”-$ & $0,2-192,6(67,5)$ & $0,7-120,2(55,7)$ & $\begin{array}{c}0,6-130,4 \\
(56,4)\end{array}$ & $22-104(82,9)$ \\
\hline $\mathrm{Mg}^{2+}$ & - " - & $0,01-47,6(9,3)$ & $0,1-66,2(10,5)$ & $\begin{array}{c}0,1-42,3 \\
(9,9)\end{array}$ & $0,6-15,8(6,4)$ \\
\hline $\mathrm{K}^{+}$ & $-"-$ & $0,04-30(10,1)$ & $0,1-45,4(6,7)$ & $0,1-25(5,9)$ & $0,2-42(4,6)$ \\
\hline $\mathrm{Sr}^{2+}$ & - ” - & $0,01-10(2,02)$ & $0,01-6,8(2,1)$ & $\begin{array}{c}0,01-7,2 \\
(1,7)\end{array}$ & $0,5-4(2,2)$ \\
\hline $\mathrm{Li}^{+}$ & мг/дм ${ }^{3}$ & $0,45-745(81,4)$ & $0,5-439(57,2)$ & $1-168(42,1)$ & $0,9-38(19,4)$ \\
\hline $\mathrm{Rb}^{+}$ & $-”-$ & $0,05-184(14,5)$ & $0,1-98(1,3)$ & $\begin{array}{c}0,05-130 \\
(7,8)\end{array}$ & $1,6-10(2,9)$ \\
\hline $\mathrm{Cs}^{+}$ & $-"-$ & $0,09-13(1)$ & $0,3-2(0,7)$ & $0,01-3(0,2)$ & - \\
\hline $\mathrm{Cu}^{2+}$ & -" - & $0,04-12(1,7)$ & $0,08-12,9(1,4)$ & $0,03-42(1,1)$ & $1-2(1,7)$ \\
\hline $\mathrm{Zn}^{2+}$ & - ”- & $0,1-375(35,7)$ & $0,2-1100(55,1)$ & $\begin{array}{c}0,002-400 \\
(29,3)\end{array}$ & $2,7-98(30)$ \\
\hline $\mathrm{Pb}^{2+}$ & $-"$ & $0,01-20(6,5)$ & $0,5-16(1,1)$ & $\begin{array}{c}0,06-11,5 \\
(1,5)\end{array}$ & 2 \\
\hline $\mathrm{Mn}^{2+}$ & - ”- & $0,4-704(50,2)$ & $2-994(127,2)$ & $\begin{array}{c}0,01-1000 \\
(100)\end{array}$ & $72-210(130,3)$ \\
\hline $\mathrm{NH}_{4}^{+}$ & - ”- & $\begin{array}{c}0,03-2500 \\
(399,8)\end{array}$ & $\begin{array}{c}0,03-1183 \\
(249,8) \\
\end{array}$ & $\begin{array}{c}0,03-7500 \\
(231,7)\end{array}$ & $24-313(118,2)$ \\
\hline $\mathrm{SiO}_{2}$ & - ” - & $0,2-1344(66,5)$ & $0,2-66(25,1)$ & $\begin{array}{c}0,3-102 \\
(23,2)\end{array}$ & 95 \\
\hline $\mathrm{Al}^{+}$ & - ”- & $0,1-350(12,7)$ & $0,02-120(7,9)$ & $0,02-23(4,3)$ & 640 \\
\hline $\mathrm{B}^{+}$ & - ”- & 5-4133 $(157,8)$ & 0,03-200 (41,9) & $\begin{array}{c}0,01-583 \\
\text { (39) }\end{array}$ & $4,9-36(12,5)$ \\
\hline $\mathrm{Fe}_{\text {общ }}$ & - ” - & $0,1-4160(201,2)$ & $0,1-1746(198,8)$ & $\begin{array}{c}0,1-3000 \\
(155,4)\end{array}$ & $\begin{array}{l}0,3-380 \\
(131,5)\end{array}$ \\
\hline$M^{*}$ & г/дм ${ }^{3}$ & $\begin{array}{c}84,6-555,9 \\
(335,3)\end{array}$ & $\begin{array}{c}93,4-583,1 \\
(325,4)\end{array}$ & $\begin{array}{c}170,3-470,1 \\
(318,6)\end{array}$ & $\begin{array}{c}278,9-398,8 \\
(350,8)\end{array}$ \\
\hline $\mathrm{pH}$ & д.е. & $3,1-7,0(5,2)$ & $3,3-6,8(5,0)$ & $3,0-6,5(5,2)$ & $3,2-6,5(5,0)$ \\
\hline $\mathrm{rNa} / \mathrm{rCl}$ & д.е. & $0,01-1(0,33)$ & $0,01-1,01(0,39)$ & $0,01-1,55$ & $0,08-0,72$ \\
\hline
\end{tabular}




\begin{tabular}{|c|c|c|c|c|c|}
\hline & & & & $(0,39)$ & $(0,27)$ \\
\hline $\mathrm{Cl} / \mathrm{Br}$ & $-"-$ & 26-1054 (119) & $23-910(202)$ & $18-939$ (659) & 39-755 (114) \\
\hline $\mathrm{Ca} / \mathrm{Cl}$ & $-”-$ & $0,01-0,79(0,31)$ & $0,01-0,74(0,26)$ & $\begin{array}{c}0,01-0,74 \\
(0,26)\end{array}$ & $\begin{array}{c}0,12-0,44 \\
(0,37) \\
\end{array}$ \\
\hline $\mathrm{Sr} / \mathrm{Cl} \cdot 10^{3}$ & $-”-$ & $\begin{array}{c}0,36-233,5 \\
(10,6)\end{array}$ & $\begin{array}{c}0,01-137,4 \\
(11,1)\end{array}$ & $\begin{array}{c}0,01-137,2 \\
(8,8)\end{array}$ & $2,9-17,6(10,3)$ \\
\hline $\mathrm{Br} / \mathrm{Cl} \cdot 10^{3}$ & $-”-$ & $0,02-39,2(15,8)$ & $0,01-43,1(16,5)$ & $\begin{array}{c}0,01-993,3 \\
(18,9) \\
\end{array}$ & $0,9-25,2(13,9)$ \\
\hline$S$ & $-"-$ & $15-552(295)$ & 6-842 (249) & 7-842 (236) & $117-501(270)$ \\
\hline $\begin{array}{c}\text { Химическ } \\
\text { ий состав } \\
\text { рассолов } \\
\text { (по } \\
\text { С.А. Щук } \\
\text { ареву) }\end{array}$ & & $\begin{array}{c}\mathrm{Cl} \mathrm{Na}, \mathrm{Cl} \mathrm{Na}- \\
\mathrm{Ca}, \mathrm{Cl} \mathrm{Na}-\mathrm{Mg} \text {, } \\
\mathrm{Cl} \mathrm{Ca}, \mathrm{Cl} \mathrm{Ca}-\mathrm{Na} \text {, } \\
\mathrm{Cl} \mathrm{Ca}-\mathrm{Na}-\mathrm{Mg}, \\
\mathrm{Cl} \mathrm{Ca-} \mathrm{Mg-Na}, \\
\mathrm{Cl} \mathrm{Ca-Mg,} \mathrm{Cl} \\
\text { Mg-Ca } \\
\end{array}$ & \multicolumn{2}{|c|}{$\begin{array}{c}\text { Cl Na, Cl Na-Ca, Cl Na-Ca-Mg, } \\
\text { Cl Na-Mg, Cl Na-Mg-Ca, Cl } \\
\text { Ca, Cl Ca-Na, Cl Ca-Na-Mg, Cl } \\
\text { Ca-Mg, Cl Mg, Cl Mg-Ca, Cl } \\
\text { Mg-Na }\end{array}$} & $\begin{array}{c}\mathrm{Cl} \mathrm{Ca}, \mathrm{Cl} \mathrm{Ca}- \\
\mathrm{Na}\end{array}$ \\
\hline $\begin{array}{c}\text { Кол-во } \\
\text { анализов }\end{array}$ & & 281 & 229 & 475 & 39 \\
\hline
\end{tabular}

Примечание: минимум-максимум (среднее); * - общая минерализация. 
Таблица 2.

Типовые анализы рассолов вендских отложений Сибирской платформы

\begin{tabular}{|c|c|c|c|c|c|c|c|c|c|c|c|c|c|c|}
\hline \multirow{2}{*}{ Площадь } & \multirow{2}{*}{$\begin{array}{l}\text { № } \\
\text { СКв. }\end{array}$} & \multirow{2}{*}{ Интервал, м } & \multirow{2}{*}{$\begin{array}{c}\mathrm{M}, \\
\Gamma / \mathrm{gM}^{3}\end{array}$} & \multicolumn{8}{|c|}{ Элементы, г/дм ${ }^{3}$} & \multicolumn{3}{|c|}{ Элементы, мг/дм ${ }^{3}$} \\
\hline & & & & $\mathrm{Na}^{+}$ & $\mathrm{K}^{+}$ & $\mathrm{Ca}^{2+}$ & $\mathrm{Mg}^{2+}$ & $\mathrm{Cl}^{-}$ & $\mathrm{SO}_{4}{ }^{2-}$ & $\mathrm{HCO}_{3}^{-}$ & $\mathrm{Br}^{-}$ & $\mathrm{B}^{+}$ & $\mathrm{I}^{-}$ & $\mathrm{Sr}^{2+}$ \\
\hline \multicolumn{15}{|c|}{ Вилючанский региональный горизонт } \\
\hline Талаканская & 804 & $1880-1890$ & 297,4 & 85,6 & 1,3 & 22,0 & 3,7 & $\begin{array}{c}183, \\
4\end{array}$ & 0,40 & 0,04 & 1,0 & 5 & 3 & 536 \\
\hline Верхневилючанская & 602 & $2633-2665$ & 337,3 & 56,4 & 1,0 & 66,0 & 2,5 & $\begin{array}{c}209, \\
2\end{array}$ & 0,10 & 0,01 & 2,2 & 8 & - & 2190 \\
\hline Нижнехамакинская & 842 & $1752-1763$ & 371,5 & 12.2 & 4,1 & 98.2 & 15,8 & $\begin{array}{c}236 . \\
9\end{array}$ & 0,10 & - & 4,2 & 5 & 12 & 1290 \\
\hline $\begin{array}{c}\text { Вилюйско- } \\
\text { Джербинская }\end{array}$ & 645 & $2435-2456$ & 377,3 & 33,4 & - & 92,2 & 7,2 & $\begin{array}{c}236, \\
1\end{array}$ & 0,20 & 0,30 & 4,7 & 6 & 12 & 2800 \\
\hline Верхневилючанская & 609 & $2572-2580$ & 384,4 & 26,3 & - & 99,8 & 10,5 & $\begin{array}{c}247, \\
4\end{array}$ & 0,03 & 0,10 & 5,6 & - & 106 & 4000 \\
\hline \multicolumn{15}{|c|}{ Непский региональный горизонт } \\
\hline Собинская & 35 & 2632-2639 & 300,4 & 87,5 & 2,5 & 16,4 & 6,6 & $\begin{array}{c}183, \\
4\end{array}$ & 1,10 & 0,10 & 2,9 & 15 & 30 & - \\
\hline Енгидинская & 154 & $2212-2271$ & 369,0 & 43,8 & 11,2 & 61,6 & 14,5 & $\begin{array}{c}231, \\
9\end{array}$ & 0,20 & 0,20 & 5,5 & 200 & 10 & 1002 \\
\hline Непская & 7 & $2637-2652$ & 407,8 & 33,7 & 9,4 & 85,3 & 15,8 & $\begin{array}{c}254, \\
5\end{array}$ & 0,10 & 0,30 & 6,7 & - & 2 & 3826 \\
\hline Верхоленская & 100 & 2912-3032 & 411,5 & 24,5 & 25,0 & 90,2 & 12,2 & $\begin{array}{c}252, \\
1\end{array}$ & 0,10 & 0,60 & 6,7 & 332 & 11 & 1680 \\
\hline Балаганкинская & 2 & 2888-2949 & 470,1 & 16,6 & 18,8 & 126,3 & 9,7 & $\begin{array}{c}290, \\
9\end{array}$ & 0,10 & 0,60 & 6,9 & 68 & - & 2788 \\
\hline \multicolumn{15}{|c|}{ Тирский региональный горизонт } \\
\hline Ковыктинская & 281 & 2997-3061 & 290,0 & 60,7 & 3,0 & 42,1 & 3,0 & $\begin{array}{c}178, \\
0\end{array}$ & 0,70 & 0,04 & 2,5 & 8 & 5 & - \\
\hline Братская & 18 & $3250-3261$ & 339,1 & 80,6 & 6,8 & 38,3 & 9,3 & $\begin{array}{c}198, \\
4\end{array}$ & 0,40 & 0,50 & 3,6 & - & 50 & 1777 \\
\hline
\end{tabular}




\begin{tabular}{|c|c|c|c|c|c|c|c|c|c|c|c|c|c|c|}
\hline Шамановская & 15 & 2615-2623 & 362,8 & 75,1 & 2,6 & 56,3 & 8,2 & $\begin{array}{c}216, \\
0\end{array}$ & 0,60 & 0,10 & 3,9 & - & - & 2172 \\
\hline Аянская & 68 & 2504-2590 & 396,9 & 46,1 & - & 90,0 & 5,4 & $\begin{array}{c}245 \\
9\end{array}$ & 0,15 & 0,04 & 5,8 & 55 & 1 & 7250 \\
\hline Шамановская & 16 & $2548-2652$ & 519,2 & 3,1 & 2,9 & 111,0 & 51,9 & $\begin{array}{c}338, \\
8\end{array}$ & 0,02 & 0,39 & 11,1 & - & 21 & 5670 \\
\hline \multicolumn{15}{|c|}{ Даниловский региональный горизонт } \\
\hline Оленчиминская & 152 & $2030-2248$ & 290,6 & 64,5 & 14,0 & 34,1 & 1,2 & $\begin{array}{c}\text { 174, } \\
9\end{array}$ & 1,40 & 0,20 & 0,2 & 20 & 4 & 300 \\
\hline Даниловская & 14 & 1825-1906 & 300,7 & 106,9 & 3,5 & 6,0 & 1,2 & $\begin{array}{c}180, \\
5\end{array}$ & 2,07 & 0,07 & 0,3 & - & - & 1750 \\
\hline Алтыбская & 244 & $1795-1800$ & 386,9 & 16,4 & 11,7 & 96,2 & 13,4 & $\begin{array}{c}241, \\
8\end{array}$ & 0,09 & 0,79 & 6,4 & 316 & 8 & 1527 \\
\hline Огневская & 132 & 2184-2325 & 433,4 & 16,8 & 20,7 & 105,2 & 14,0 & $\begin{array}{c}271, \\
6\end{array}$ & 0,03 & 0,09 & 3,8 & 50 & 32 & 1000 \\
\hline Кутурминская & 156 & 3054-3188 & 555,9 & 3,63 & 14,1 & 153,8 & 20,3 & 354, & 0,10 & 0,12 & 9,8 & - & - & - \\
\hline
\end{tabular}




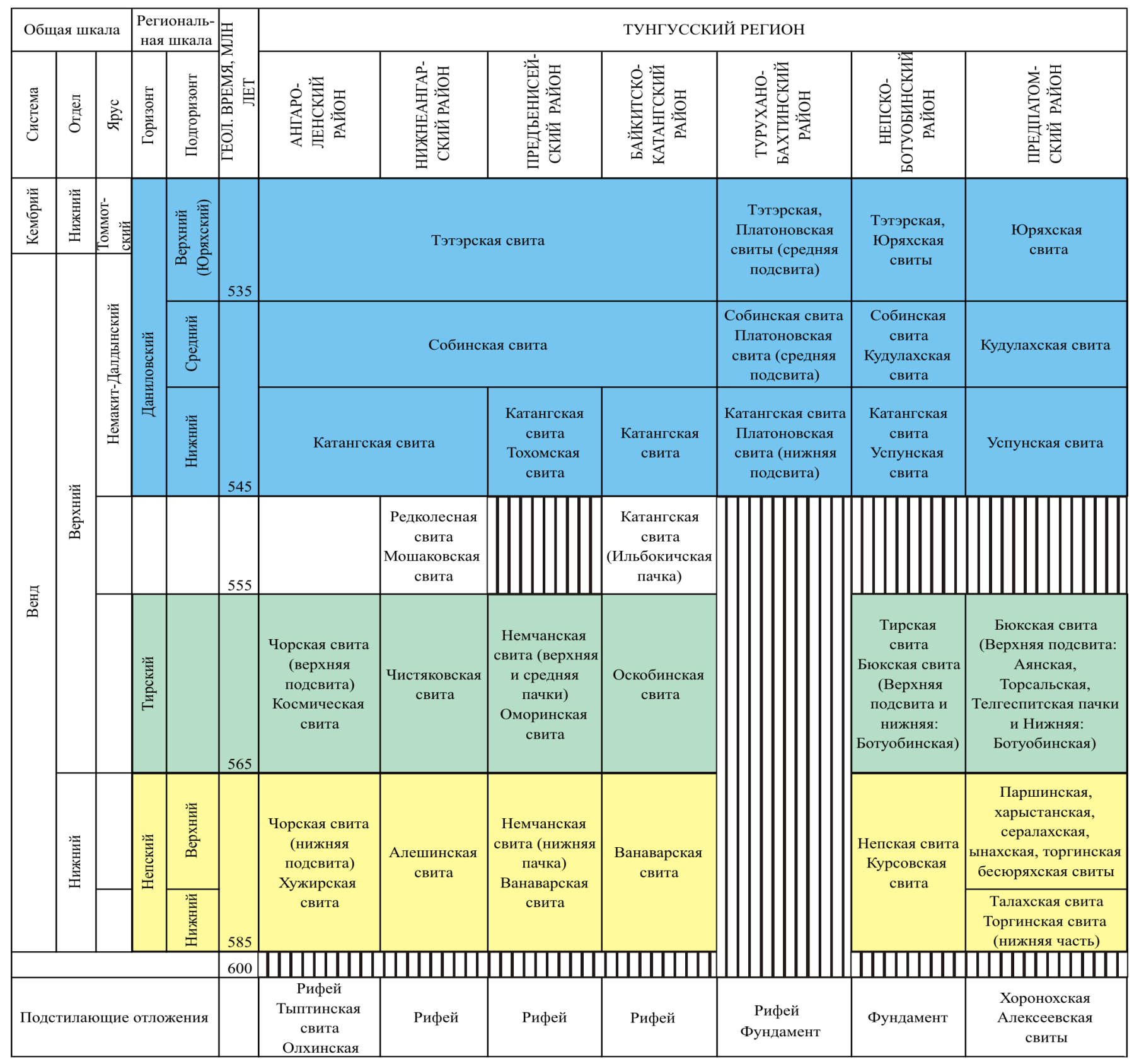

\section{ППП Отсутствие отложений}




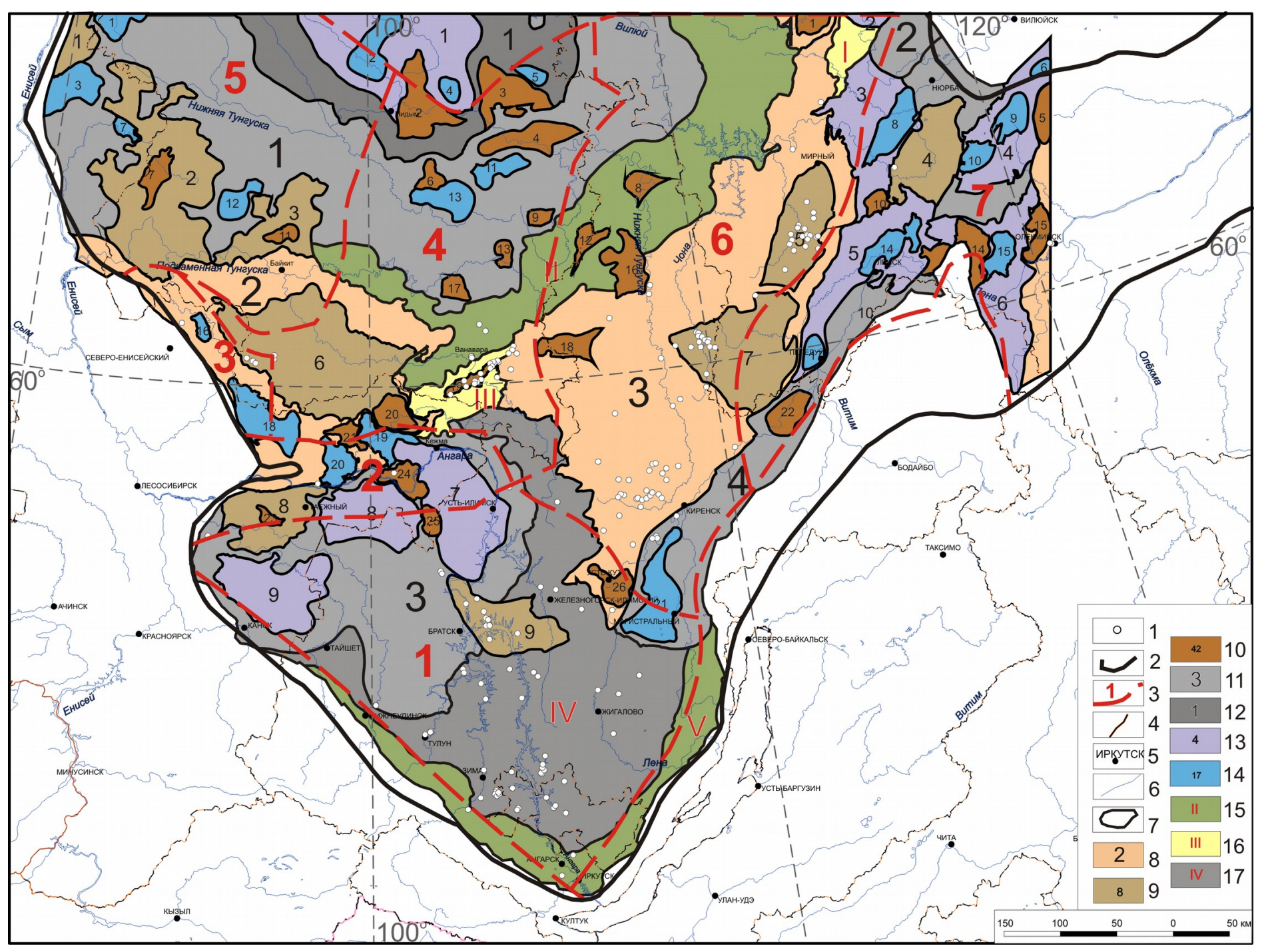




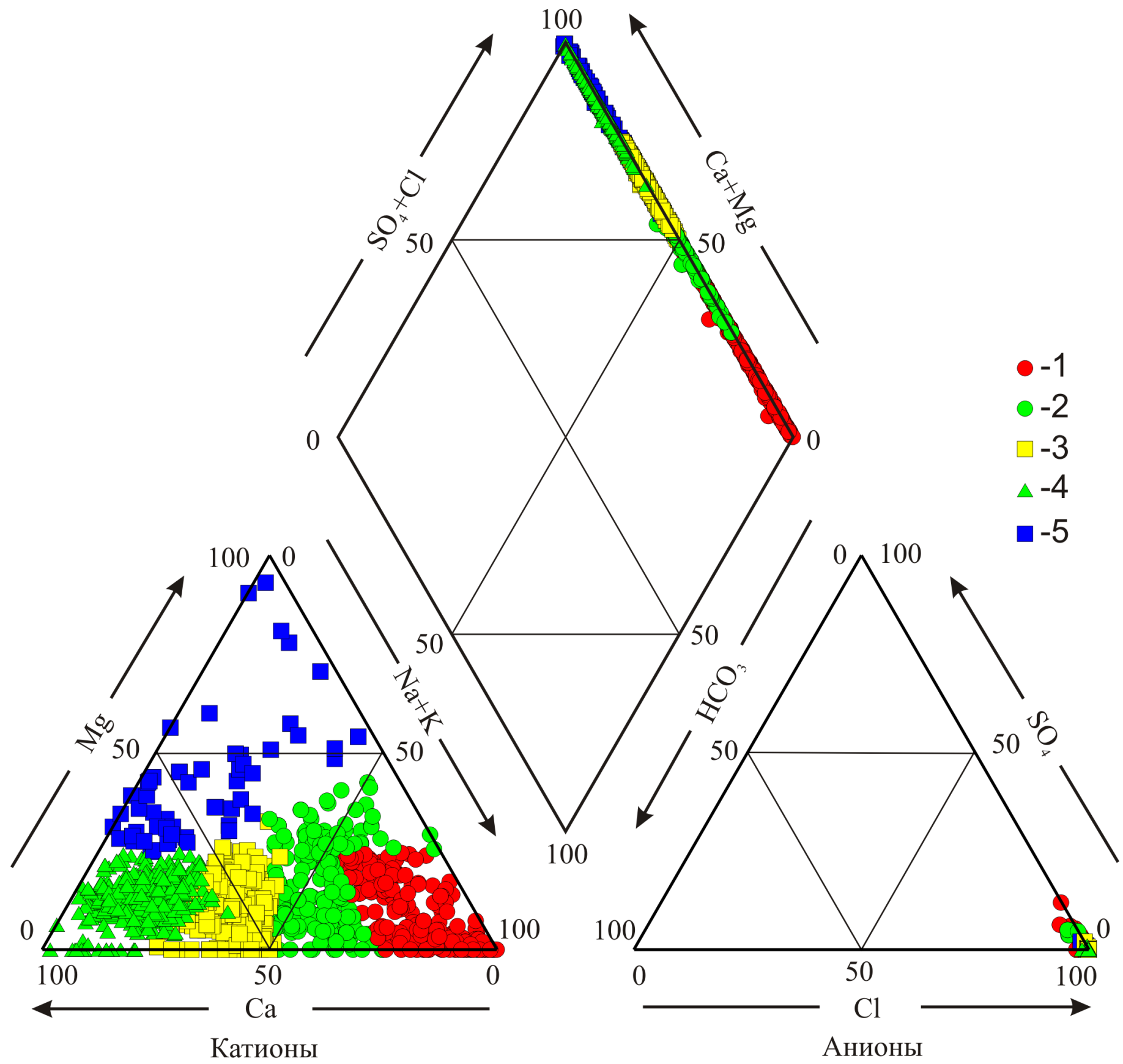




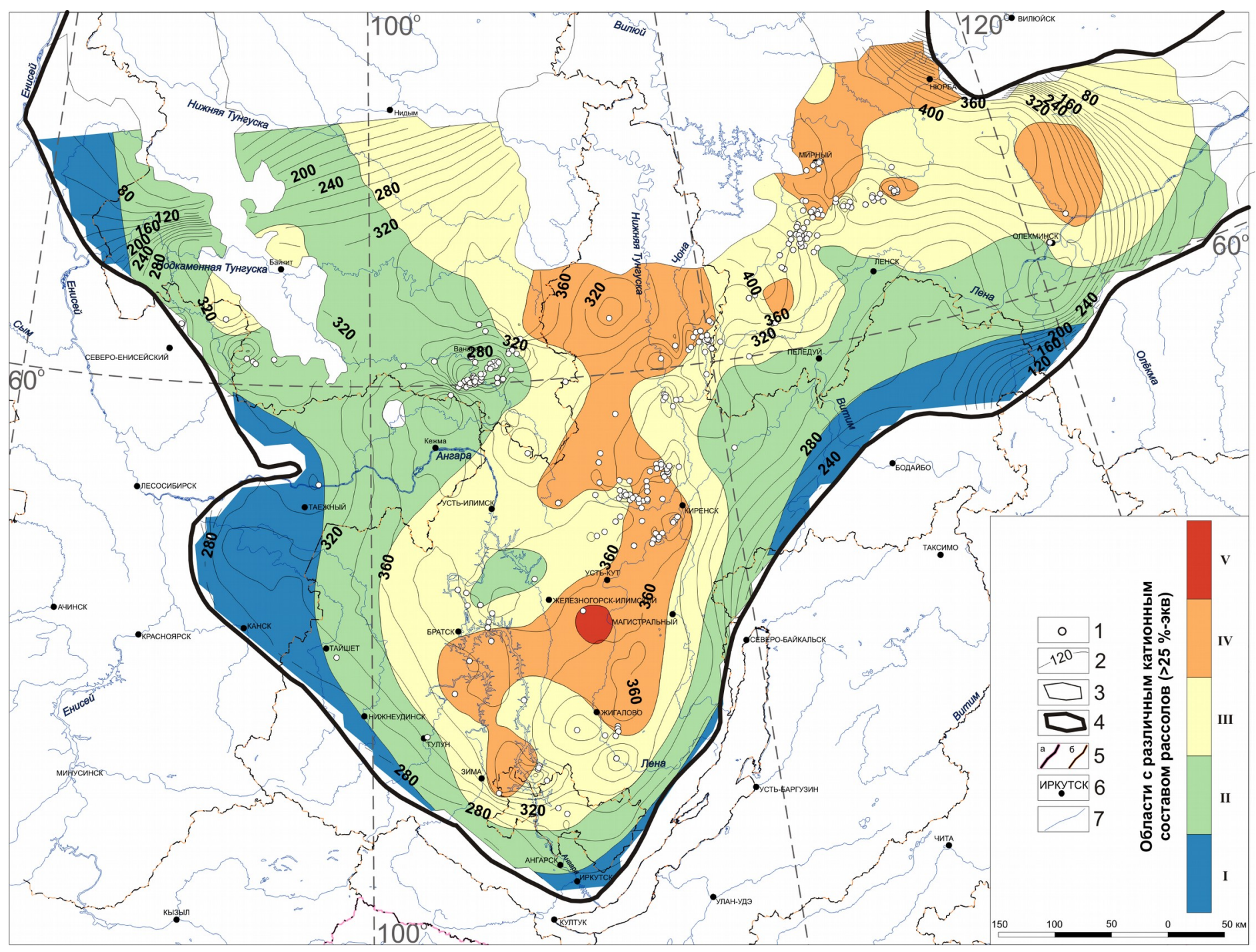




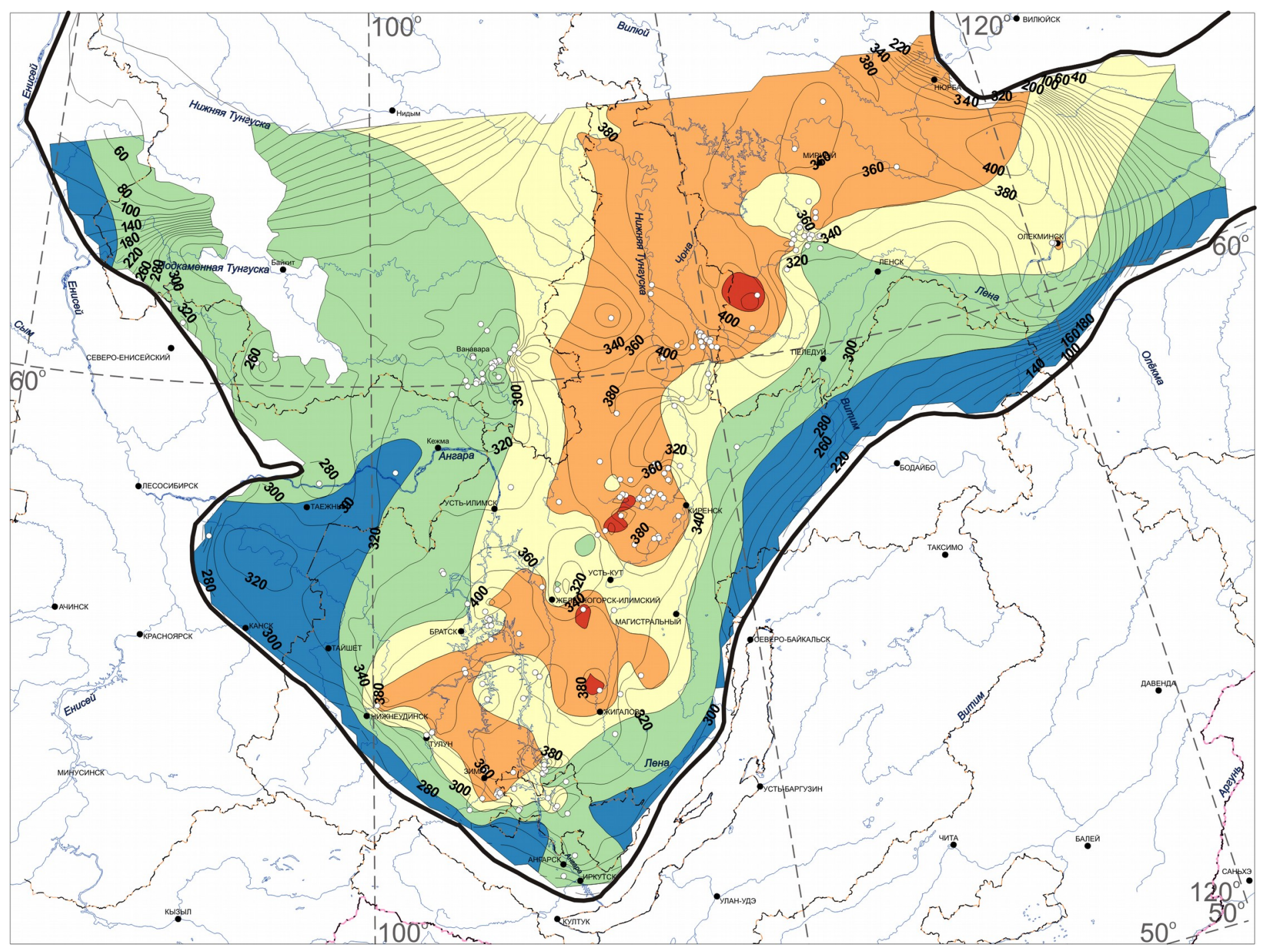



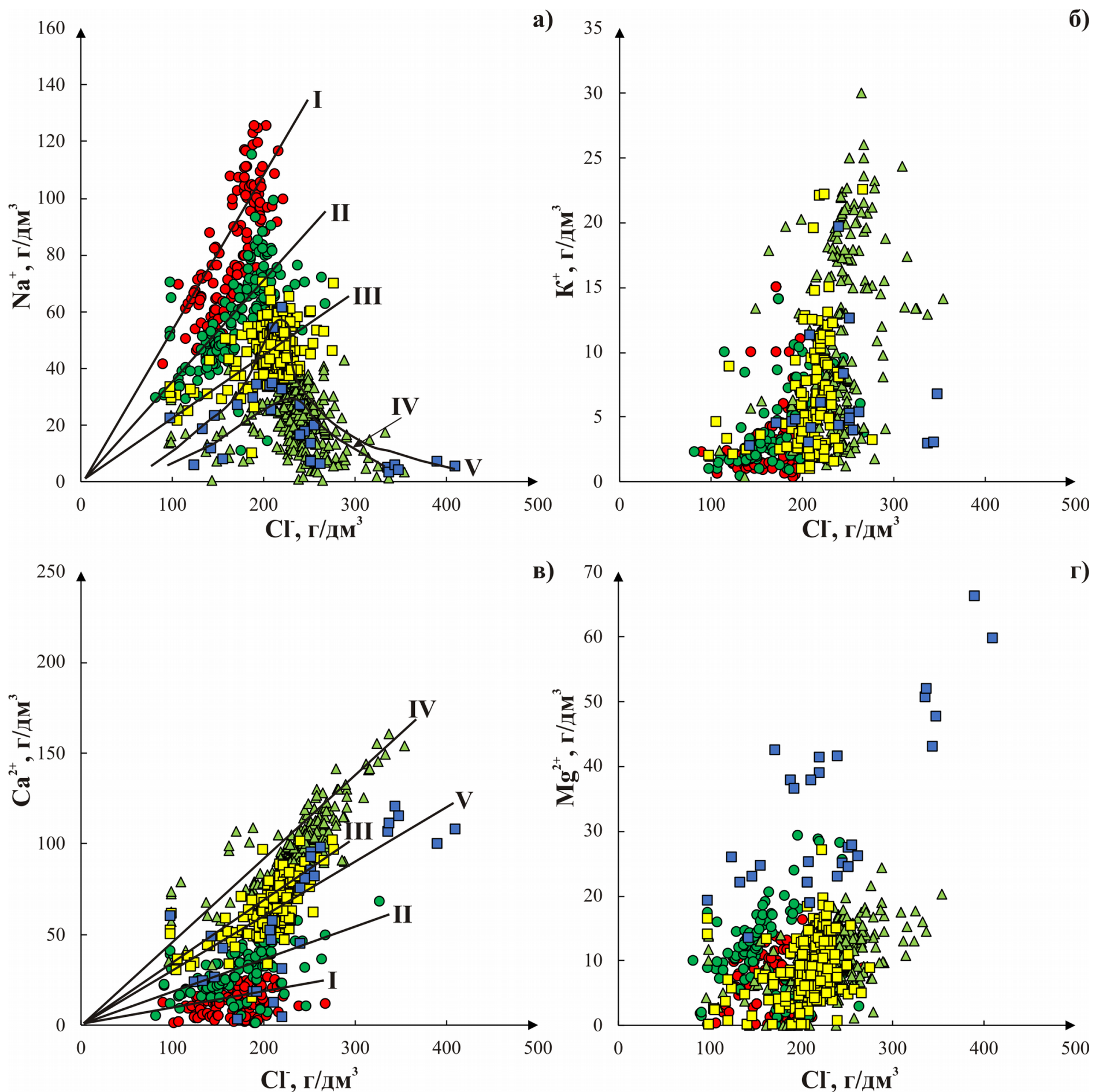

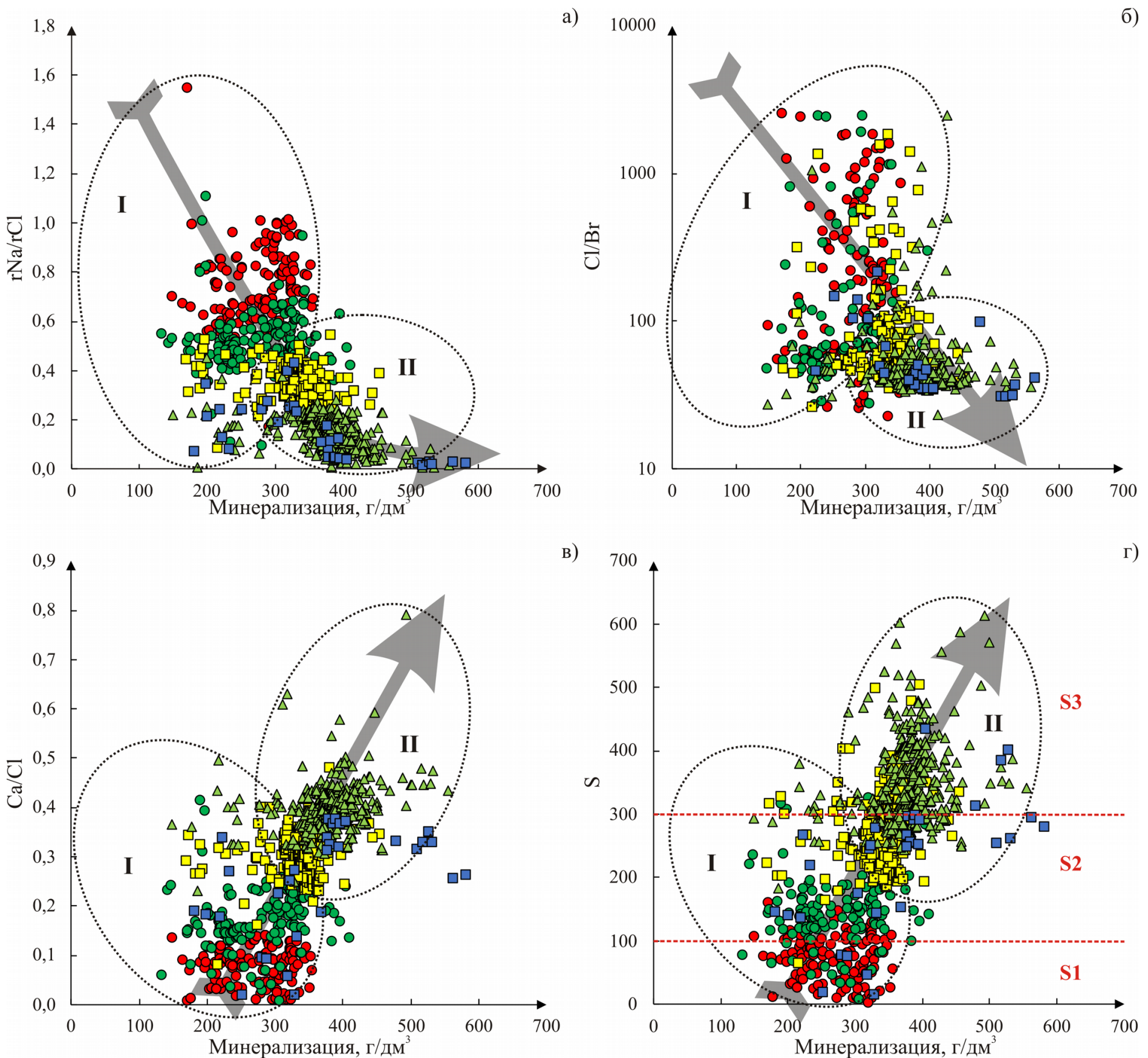

B) 700

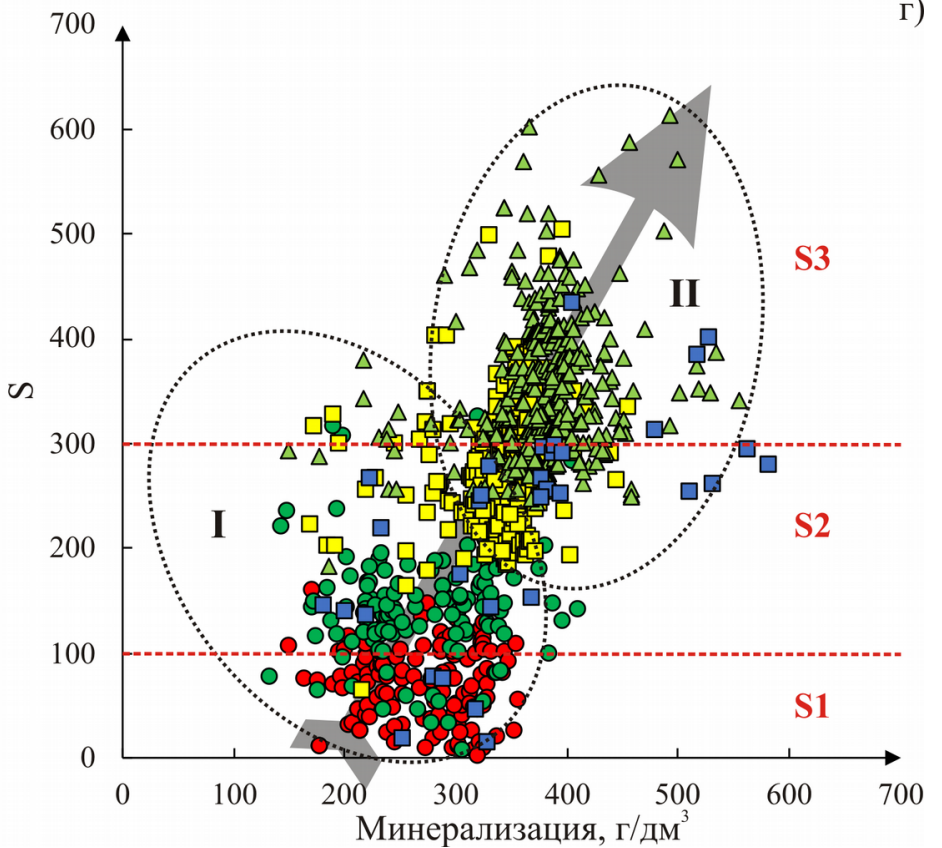

